This work is licensed under a Creative Commons Attribution License (CC BY 4.0).

\title{
Six new species of Tipula (Vestiplex) Bezzi (Diptera, Tipulidae) from Tibet
}

\author{
Qi-cheng YANG ${ }^{1}$, Yan $\mathrm{LI}^{2}$, Zhao-hui PAN ${ }^{3}$, Xiao-yan LIU ${ }^{\circledR}$ 4,* $\&$ Ding YANG ${ }^{5, *}$ \\ ${ }^{1,4}$ Hubei Insect Resources Utilization and Sustainable Pest Management Key Laboratory, College of \\ Plant Science \& Technology of Huazhong Agriculture University, Wuhan, Hubei, 430070, China. \\ ${ }^{2}$ Plant Protection College, Shenyang Agricultural University, Shenyang, Liaoning, 110866, China. \\ ${ }^{3}$ Institute of Plateau Ecology, Tibet Agriculture \& Animal Husbandry University, Linzhi, \\ Xizang, P.R. 860000, China. \\ ${ }^{5}$ China Agricultural University, Beijing, 100193, China. \\ *Corresponding authors: liuxiaoyan@mail.hzau.edu.cn; yangding@cau.edu.cn \\ 1Email: qichengyang@foxmail.com \\ ${ }^{2}$ Email: liyan_syau@163.com \\ 33Email: panzhaohui2005@163.com

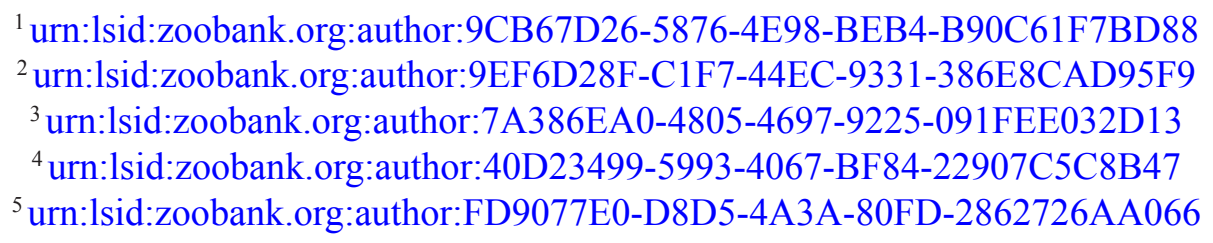

\begin{abstract}
Twelve species of the subgenus Vestiplex (Diptera, Tipulidae) were previously known to occur in Tibet (= Xizang), China. Here, six species are described and illustrated as new to science: Tipula (Vestiplex) bucera sp. nov., Tipula (Vestiplex) magatama sp. nov., Tipula (Vestiplex) motuoensis sp. nov., Tipula (Vestiplex) nayogabuensis sp. nov., Tipula (Vestiplex) platyphylla sp. nov. and Tipula (Vestiplex) uncinella sp. nov. The following three species are redescribed: Tipula (Vestiplex) himalayensis Brunetti, 1911, Tipula (Vestiplex) nigroapicalis Brunetti, 1911 and Tipula (Vestiplex) zayulensis Alexander, 1963. A key to the species of Tipula (Vestiplex) from Tibet is presented.
\end{abstract}

Keywords. Crane flies, new species, Tibet, Tipulinae, Vestiplex.

Yang Q., Li Y., Pan Z., Liu X. \& Yang D. 2021. Six new species of Tipula (Vestiplex) Bezzi (Diptera, Tipulidae) from Tibet. European Journal of Taxonomy 764: 152-192. https://doi.org/10.5852/ejt.2021.764.1477

\section{Introduction}

The tipulid subgenus Tipula (Vestiplex) was erected by Bezzi (1924) for the species Tipula cisalpina Riedel, 1913 and T. hemapterandra Bezzi, 1924. The subgenus currently includes 178 known species and subspecies worldwide, which are distributed in the Holarctic (112 taxa) and the Oriental Realms (76 taxa) (Oosterbroek 2021). To date, 76 species are known from China, including 12 species from Tibet 
Autonomous Region (hereafter abbreviated as Tibet). Most species of this subgenus have variegated wings, while some species have reduced wings. The male tergite 9 commonly forms a shallowly concave sclerotized saucer or can be longitudinally divided into two parts, some species have two pubescent finger-like arms. The female ovipositor is commonly with saerrated outer margin (Alexander 1935, 1965; Savchenko 1964; Alexander \& Byers 1981; Starkevich \& Podenas 2011; Starkevich 2012; Men et al. 2017).

The currently described species of the subgenus Vestiplex are prevalent in the Holarctic and Oriental zoogeographical regions. The majority of the species are related to mountain systems (Alps, Pyrénées, Caucasus and Himalayas), at altitudes up to $4500 \mathrm{~m}$ a.s.l. Adults are often found in broad-leaved, mixed coniferous woods, rock meadows, steppes and tundras (Savchenko 1960, 1964; Starkevich 2012). The Qinghai-Tibetan Plateau (QTP) is the largest and highest plateau in the world with an average elevation above $4000 \mathrm{~m}$. The uplift and formation of the QTP has strongly influenced the climate, environment and evolution of biota in this region (Li \& Fang 1999). The QTP has an important status in zoogeographical regionalization, which spans three biodiversity hotspots in the world, including the mountains of Southwest China, the Himalaya, and the Indo-Burma, respectively (Li et al. 2019). Tibet is located in southwest China and the Qinghai-Tibet Plateau with its peculiar biodiversity in Asia. It mostly belongs to the Palaearctic Region except that southern Tibet is considered as Oriental ( $\mathrm{Su}$ et al. 2019). The following 12 species of Vestiplex are known to occur in Tibet: Tipula (Vestiplex) adungensis Alexander, 1963, T. (V.) alyxis Alexander, 1963, T. (V.) avicularia Edwards, 1928, T. (V.) distifurca Alexander, 1942, T. (V.) eurydice Alexander, 1961, T. (V.) himalayensis Brunetti, 1911, T. (V.) nigroapicalis Brunetti, 1911, T. (V.) opilionimorpha opilionimorpha Savchenko, 1955, T. (V.) rongtoensis Alexander, 1963, T. (V.) scandens Edwards, 1928, T. (V.) subscripta Edwards, 1928 and T. (V.) zayulensis Alexander, 1963 (Oosterbroek 2021). In this paper, six new species are added to the fauna of Tibet, and descriptions with illustrations of three previously known species have been added to improve the recognition of these taxa. A key to the species of Vestiplex in Tibet is presented.

\section{Material and methods}

The specimens were studied and illustrated with ZEISS Stemi 2000-c stereo microscope. Details of coloration were checked in specimens immersed in $75 \%$ ethyl alcohol $\left(\mathrm{C}_{2} \mathrm{H}_{5} \mathrm{OH}\right)$, to observe pruinescence specimens were examined in dry condition, some specimens were not soaked in alcohol. Genitalic preparations of males were made by immersion in a heated Lactic acid solution $\left(\mathrm{C}_{3} \mathrm{H}_{6} \mathrm{O}_{3}>85 \%, 95-97^{\circ} \mathrm{C}\right)$ for 4-6 minutes and cooled down to room temperature. After examination, genitalia were transferred to fresh glycerine $\left(\mathrm{C}_{3} \mathrm{H}_{8} \mathrm{O}_{3}\right)$ and stored in a microvial attached to the specimen. Type specimens are deposited in the Entomological Museum of China Agricultural University (CAU), Beijing. All pictures were adjusted and assembled into plates with Adobe Photoshop CS6. The morphological terminology mostly follows Gelhaus (2005), Cumming \& Wood (2017), de Jong (2017) and Starkevich et al. (2020). Species group definitions follows Starkevich (2012).

\section{Institutional acronyms}

$\mathrm{BMNH}=$ Natural History Museum, London, UK

$\mathrm{CAU}=$ China Agricultural University, Beijing, China

USNM = National Museum of Natural History, Washington, US

ZSI $=$ Zoological Survey of India, India

Place name interpretation (Chinese, Chinese Pinyin and Tibetan Pinyin):

波密 $=$ Bomi $=$ Bome

察隅 $=$ Chayu $=$ Zayu

墨脱 $=$ Motuo $=$ Medog 


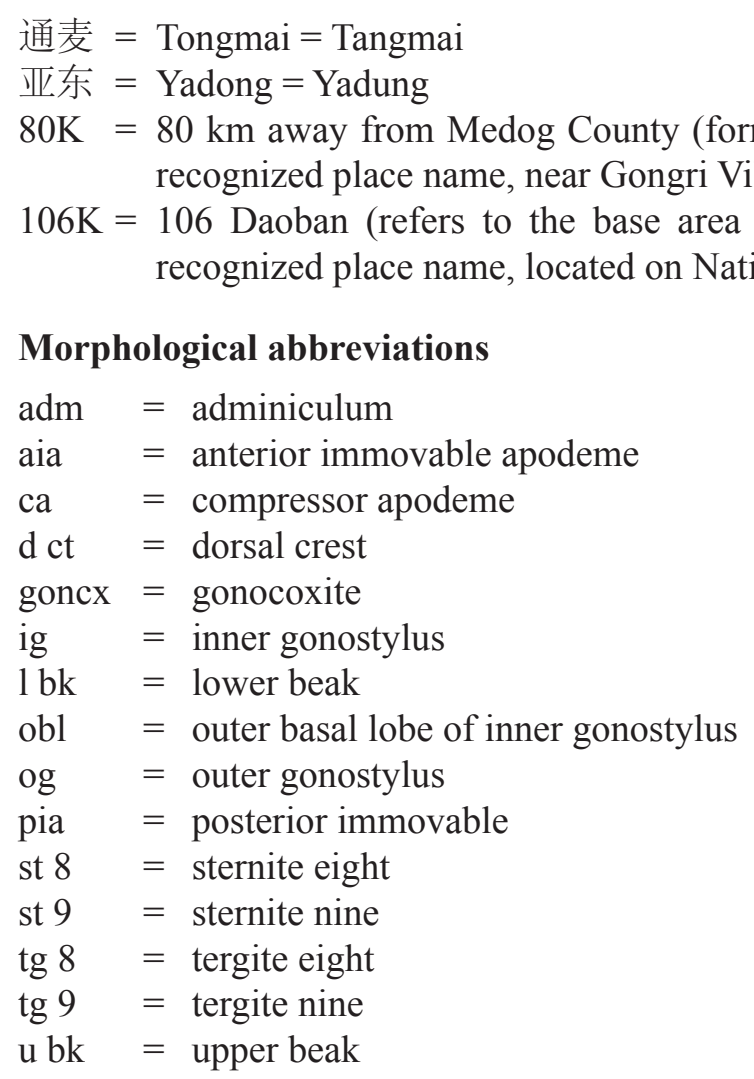

\section{Results}

Class Insecta Linnaeus, 1758

Order Diptera Linnaeus, 1758

Family Tipulidae Latreille, 1802

Subfamily Tipulinae Kertesz, 1902

Genus Tipula Linnaeus, 1758

Subgenus Vestiplex Bezzi, 1924

\section{Key to species (male) of Vestiplex from Tibet, China}

1. Posterior margin of tergite 9 broadly depressed, wide and flat 2

- Tergite 9 with appendages or divided into two parts 4

2. Wing reduced in both sexes; inner gonostylus blunt T. (V.) opilionimorpha opilionimorpha Savchenko, 1955

- Wing fully developed, or only reduced in female; inner gonostylus slender 3

3. Body mainly yellow; gonocoxite ends with strong spine T. (V.) subscripta Edwards, 1928

- Body mainly blackish; gonocoxite unarmed T. $(\boldsymbol{V}$.) scandens Edwards, 1928

4. Ventral surface of tergite 9 with a pair of appendages, strong or weak 5

- Tergite 9 without appendages, divided into two parts, lobed

5. Ventral armature of tergite 9 black and bifid T. (V.) eurydice Alexander, 1961

- Ventral armature of tergite 9 yellow or not bifid 6 
6. Arms of ventral surface of tergite 9 leaf-shaped; suture between tergite 9 and gonocoxite with a spiny projection

- Arms of ventral surface of tergite 9 not leaf-shaped; suture between tergite 9 and gonocoxite without a spiny projection

7. Ventral surface of tergite 9 with a pair of strong arms with granulated margin; without distinct appendages on sternite 9

- Arms of tergite 9 weak or smooth, without granulated margin; sternite 9 with appendages ......... 10

8. Posterior margin of gonocoxite spiny; posterior margin of inner gonostylus swollen

- Posterior margin of gonocoxite hook-like; inner gonostylus not swollen

T. (V.) motuoensis sp. nov.

9. Inner gonostylus with lower beak; outer gonostylus anteriorly bent, posterior margin of basal half truncated

T. (V.) uncinella sp. nov.

- Inner gonostylus without lower beak; outer gonostylus spoon-like ....... T. (V.) magatama sp. nov.

10. Arms of tergite 9 slender; lower beak of inner gonostylus with bent angle; apex of outer gonostylus truncated relatively

- Arms of tergite 9 not slender, lower beak of inner gonostylus without bent angle; apex of outer gonostylus oval

11. Stripe of prescutum with dark brown margin; arms of tergite 9 sharp; appendages of sternite 9 truncated at tip T. $(\boldsymbol{V}$.) adungensis Alexander, 1963

- Stripe of prescutum with pale margin; arms of tergite 9 not sharp; appendages of sternite 9 with rather acute tip T. (V.) rongtoensis Alexander, 1963

12. Posterior margin of gonocoxite short thorn-like; appendages of sternite 9 strong, bifurcate at the apex; lower beak of inner gonostylus usual

T. (V.) distifurca Alexander, 1942

- Posterior margin of gonocoxite not special or hooked; appendages of sternite 9 not bifurcate at the apex, slender or short; lower beak of inner gonostylus rolled up

13. Lower posterior margin of tergite 9 with a pair of puny arms; sternite 9 with a pair of slender appendages

T. (V.) nayogabuensis sp. nov.

- Arms of tergite 9 strong; appendages of sternite 9 short T. (V.) zayulensis Alexander, 1963

14. Adminiculum trident-shaped 15

- Adminiculum not trident-shaped

15. Outer gonostylus with protrusion; sternite 9 with appendages .... $\boldsymbol{T}$. $(\boldsymbol{V}$.) nigroapicalis Brunetti, 1911

- Outer gonostylus without protrusion; sternite 9 without appendages

16. Lower posterior margin of gonocoxite with abundant long setae; lateral processes of adminiculum very short $T$. (V.) bucera sp. nov.

- Lower posterior margin of gonocoxite without long setae; lateral processes of adminiculum long T. (V.) alyxis Alexander, 1963

17. Sternite 9 with appendages, the tips of which are shaped like a bird's head

- Sternite 9 without appendages T. (V.) himalayensis Brunetti, 1911 


\section{Tipula (Vestiplex) deserrata group in Tibet}

Tipula (Vestiplex) magatama sp. nov.

Tipula (Vestiplex) uncinella sp. nov.

Tipula (Vestiplex) magatama sp. nov. urn:1sid:zoobank.org:act:788D3C24-ECA9-471D-8F77-F4D688CD3C20

Figs $1-9,86$

\section{Diagnosis}

Nasus elongate, apex slightly expanded. Scape and pedicel of antenna yellow; flagellar segments 1-4 grayish yellow, other segments pale brown, except base darker. Prescutum almost wholly reddish brown with four olive-gray striped pruinescence, median stripe broadened apically and gradually narrowing to base. Posterior margin of gonocoxite with a sharp black spine. Tergite 9 separated medially, with a pair of angular arms arising from ventral surface of tergite 9, with granulated margins, apex with a small inner projection, outer surface of arms with a pair of depressions (Fig. 9). Outer gonostylus slender, spoon-like. Lower beak of inner gonostylus absent.

\section{Etymology}

The species is named after the shape of inner gonostylus, it looks like a 'Magatama', a curved commashaped bead from prehistoric Japan, called '勾玉' in China. The name is to be treated as a noun in apposition.

\section{Material examined}

\section{Holotype}

CHINA - O'; Tibet, Bomi, Yigong (易贡); 30¹6'19" N, 9448'28" E; 2270 m a.s.1.; 5-7 May 2017; Qicheng Yang leg.; light trap; CAU.

\section{Paratypes}

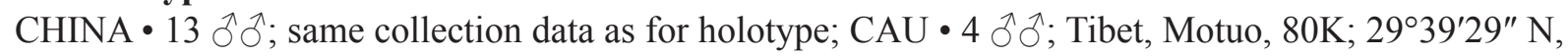
95²9'24" E; 2020 m a.s.1.; 8 May 2017; Qicheng Yang leg.; light trap; CAU.

\section{Description}

\section{Male}

Measurements. Body length 16.5-20.0 mm, wing length 21.0-24.0 mm, antenna length $2.5-3.0 \mathrm{~mm}$ $(n=18)$.

HeAD (Figs 1, 3). Mainly brownish yellow. Occipital marking brown, elongated to vertex, broadened apically and gradually narrowing to base. Rostrum and nasus grayish yellow with brown setae, nasus elongate, apex slightly expanded. Setae on head dark brown. Antenna relatively short; scape and pedicel yellow; flagellar segments 1-4 grayish yellow, other segments pale brown, except base darker. Proboscis and palpus brown.

Thorax (Figs 1, 3). Mainly reddish brown, heavily grayish yellow pruinescence. Pronotum brown with yellow setae, middle black. Prescutum almost wholly reddish brown with four olive-gray striped pruinescence, median stripe broadened apically and gradually narrowing to base. Scutum brown with two olive-gray pruinose spots. Scutellum reddish brown with dark gray pruinescence. Mediotergite dark yellow with yellow pruinescence and olive-gray mid-longitudinally. Thoracic pleuron dark yellow with grayish yellow pruinescence. Anepisternum, katepisternum and anepimeron dark brown at antero-upper corners. Anatergite and katatergite yellow. Parascutellum yellow. Meron dark yellow. Setae on thorax 

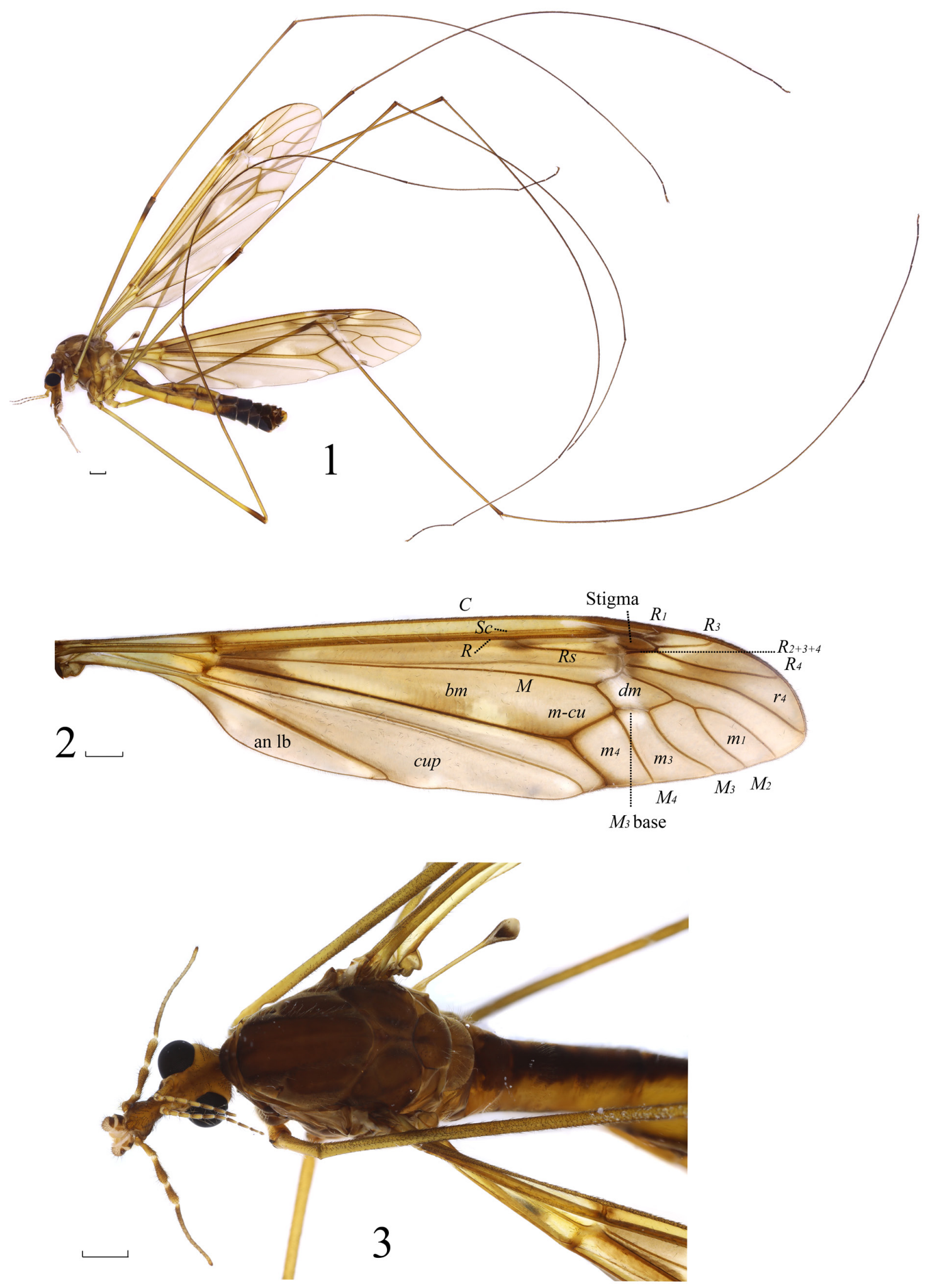

Figs 1-3. Tipula (Vestiplex) magatama sp. nov., paratype, $\widehat{\partial}$ (CAU). 1. Habitus, lateral view. 2. Wing. 3. Head and thorax, dorsal view. Abbreviations: see Material and methods. Scale bars $=1.0 \mathrm{~mm}$. 

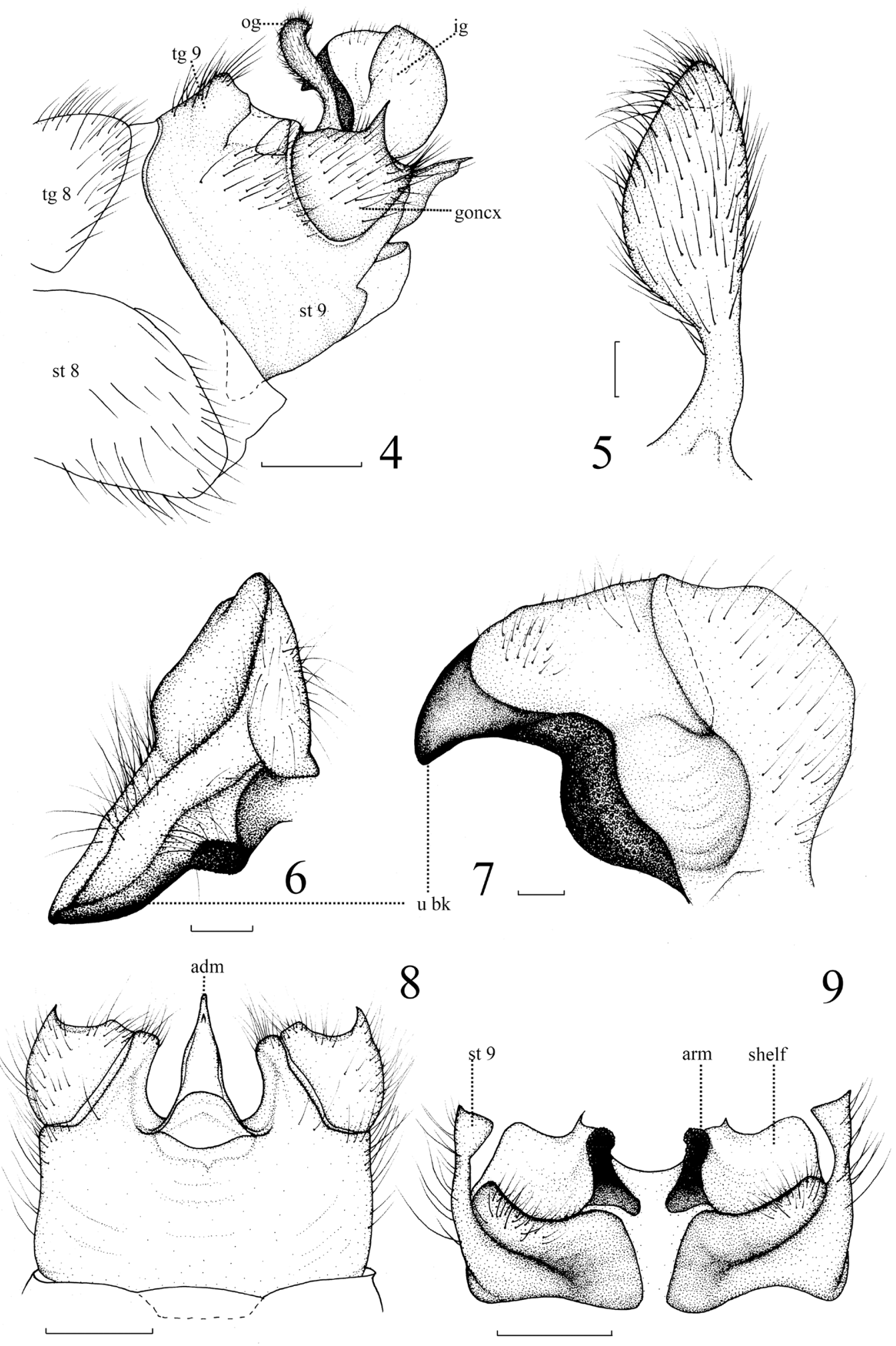

Figs 4-9. Tipula (Vestiplex) magatama sp. nov., holotype, ô (CAU). 4. Hypopygium, lateral view. 5. Outer gonostylus, lateral external view. 6-7. Inner gonostylus, dorsal view and lateral external view. 8. Hypopygium, ventral view. 9. Tergite nine, dorsal view. Abbreviations: see Material and methods. Scale bars: $4,8-9=0.5 \mathrm{~mm} ; 5-7=0.1 \mathrm{~mm}$. 
yellow. Legs with coxae and femora yellow, femora with brownish black apexes; tibiae brownish yellow with black tips. Tarsi brownish black. Setae on legs dark brown. Wing variegated brown with numerous smaller pale areas; pterostigma pale black; petiole of cell $\mathrm{m}_{1}$ distinctly shorter than discal cell (Fig. 2). Halter with stem dark yellow, knob black.

AвDomen (Figs 1, 3). Mainly dark yellow. Abdominal tergites each with three black stripes, middle stripe stout; lateral stripes relatively narrow. Abdominal segments 5-9 black. Setae on abdomen yellow.

HypOPYGIUM (Figs 4-9). Posterior margin of gonocoxite with a sharp black spine. Tergite 9 separated medially, with a pair of angular arms arising from ventral surface of tergite 9, with granulated margins, apex with a small inner projection, outer surface arms with a pair of depressions. Sternite 9 with a median prominence. Apex of adminiculum slim. Outer gonostylus slender, spoon-like, apex circular (Fig. 5). Inner gonostylus with big concavity; inner margin black sclerotized; lower beak absent; reversed side with big concavity (Figs 6-7).

\section{Female}

Unknown or unrecognized.

\section{Distribution}

China (Tibet).

\section{Remarks}

The new species is similar to $T$. (V.) yunnanensis Alexander, 1942 from Yunnan, China, but the latter differs in the following characters: posterior margin of gonocoxite with a slightly twisted spine; outer gonostylus long and slender; lower beak of inner gonostylus sharp.

Tipula (Vestiplex) uncinella sp. nov. urn:1sid:zoobank.org:act:635FCCE1-5615-49F6-B272-82142261A897

Figs 10-20, 86

\section{Diagnosis}

Scape and pedicel yellow, flagellum grayish yellow. Prescutum with four grayish yellow stripes, all stripes with brown margins. Scutellum yellow with dark brown mid-longitudinal stripe. Mediotergite yellow with brown mid-longitudinal stripe. Tergite 9 separated medially, pair of angular arms arising from ventral surface of tergite 9, arms with granulated margins. Base of posterior margin of inner gonostylus without a small protrusion; upper beak slightly twisted, lower beak curved, middle concave.

\section{Etymology}

The species is named after the uncinatus of the adminiculum, the Latin adjective 'uncinella' means 'bearing hooks, barbed'.

\section{Material examined}

\section{Holotype}

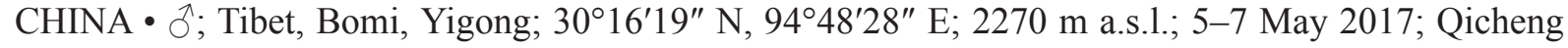
Yang leg.; sweeping net; CAU.

\section{Paratypes}

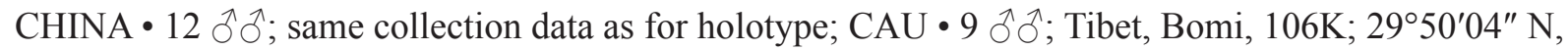
94²4'36" E; 2290 m a.s.1.; 17 May 2017; Qicheng Yang leg.; light trap; CAU. 


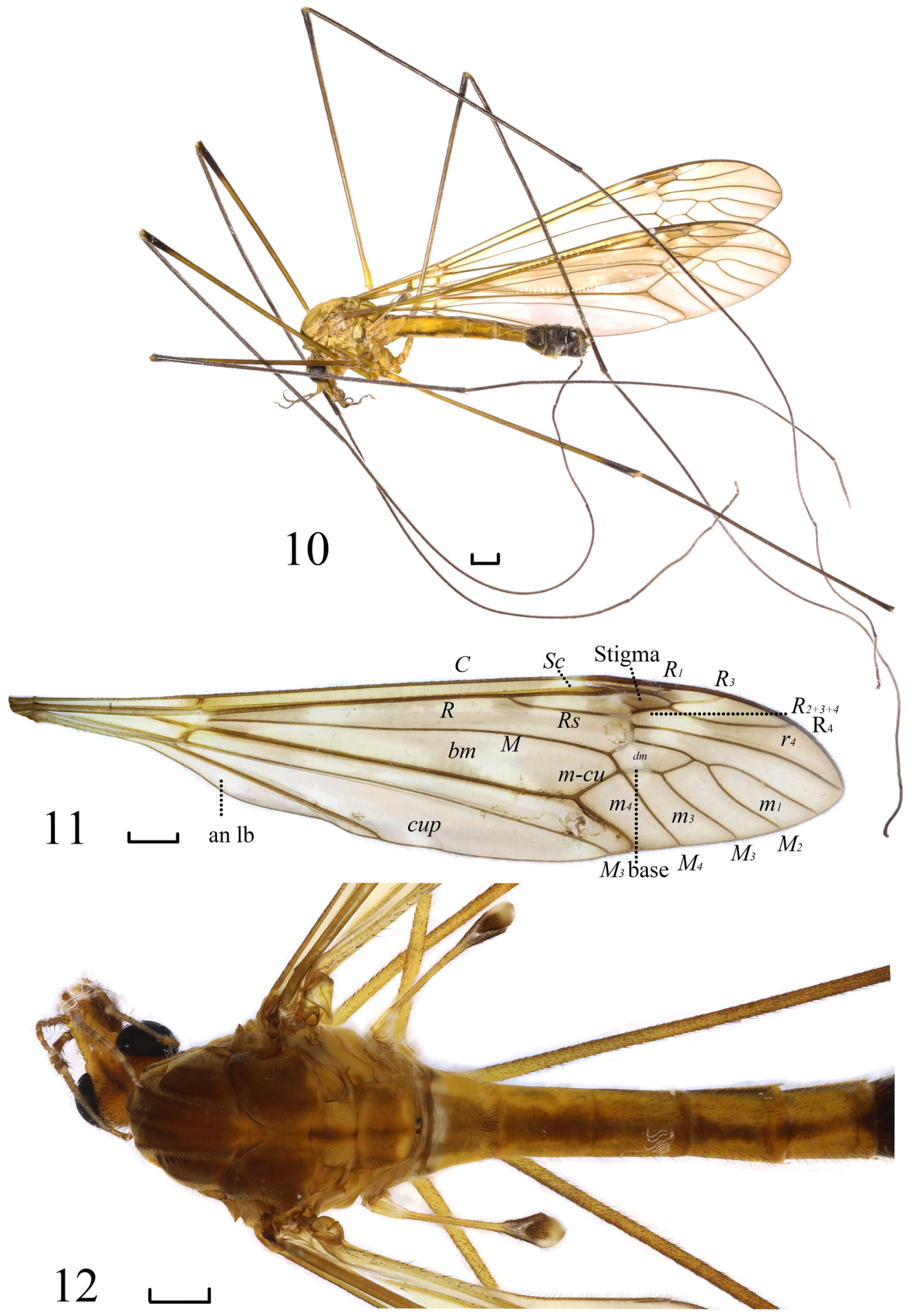

Figs 10-12. Tipula (Vestiplex) uncinella sp. nov., paratypes, $\widehat{\partial} \hat{\partial}$ (CAU). 10. Habitus, lateral view. 11. Wing. 12. Habitus, dorsal view. Abbreviations: see Material and methods. Scale bars $=1.0 \mathrm{~mm}$. 


\section{Description}

Male

MeAsurements. Body length $14.0 \mathrm{~mm}$, wing length $18.0-20.0 \mathrm{~mm}$, antenna length $3.0-3.5 \mathrm{~mm}(\mathrm{n}=22)$.

HeAd (Figs 10, 12). Mainly yellow. Occipital stripe dark gray. Rostrum and nasus yellow. Setae on head brown. Scape and pedicel yellow, flagellum grayish yellow. Proboscis and palpus brownish yellow.

Thorax (Figs 10, 12). Mainly yellow, heavily pruinose. Pronotum brownish yellow with yellow setae. Prescutum with four grayish yellow stripes, all stripes with brown margins, median stripe broadened apically and gradually narrowing to base, lateral stripes long-oval. Scutum yellow with four grayish yellow spots, anterior margins of anterior two spots brown. Scutellum yellow with dark brown midlongitudinal stripe. Mediotergite yellow with brown mid-longitudinal stripe. Thoracic pleuron yellow. Parascutellum yellow. Meron yellow. Setae on thorax yellow. Legs with coxae and femora yellow, femora with dark brown apices, tibiae and tarsi dark brown. Setae on legs dark brown. Wing variegated light brown; pterostigma brown; petiole of cell $\mathrm{m}_{1}$ distinctly shorter than discal cell (Fig. 11). Halter with stem yellow, knob pale black with pale yellow apex.

Abdomen (Figs 10, 12). Mainly yellow. Abdominal tergites each with three brown stripes. Abdominal segments 5-9 dark brown to black. Setae on abdomen brownish yellow.

Hypopygium (Figs 13-17, 20). Gonocoxite elongated, separated from sternite 9, posterior margin with an unusually strong and slender black spine, directed chiefly dorsally, slightly twisted. Tergite 9 separated medially, middle of posterior margin of lobe slightly protrude; a pair of angular black arms arising from ventral surface of tergite 9, surface of arms not smooth, with granulated margin. Sternite 9 with a median prominence. Adminiculum narrow spade-like, apex slightly furcal, ventral caudal part with a small uncinate projection. Outer gonostylus anteriorly bent, posterior margin of basal half truncated (Fig. 16). Inner gonostylus with concavity at middle, posterior margin with big semicircular bulge; base of posterior margin of inner gonostylus without a small protrusion; upper beak slightly twisted, lower beak curved, middle concave (Fig. 14). Semen pump (Figs 18-19) as shown in figures. Aedeagus wide, basal width about $0.5 \mathrm{~mm}$, gradually narrowing towards apex, and apex not bifurcated.

\section{Female}

Unknown or unrecognized.

\section{Distribution}

China (Tibet).

\section{Remarks}

The new species is similar to T. (V.) schizophallus (Alexander, 1973), but the latter differs in the following characters: arms of tergite 9 with only inner margin roughened; gonocoxite with an additional small spine (the one near posterior margin of basistylar suture); outer gonostylus with very abundant black setae from conspicuous punctures; apex of adminiculum profoundly divided into two long parallel spines, ventral caudal part without uncinatus. It is also similar $T$. (V.) deserrata Alexander, 1934 and $T$. (V.) factiosa Alexander, 1940, but the posterior margin of inner gonostylus in the latter has no protrusion. The posterior margin of tergite 9 of $T$. ( V.) factiosa is smooth, its arms are large and strong.

Tipula (Vestiplex) divisotergata group in Tibet

Tipula (Vestiplex) adungensis Alexander, 1963

Tipula (Vestiplex) rongtoensis Alexander, 1963 

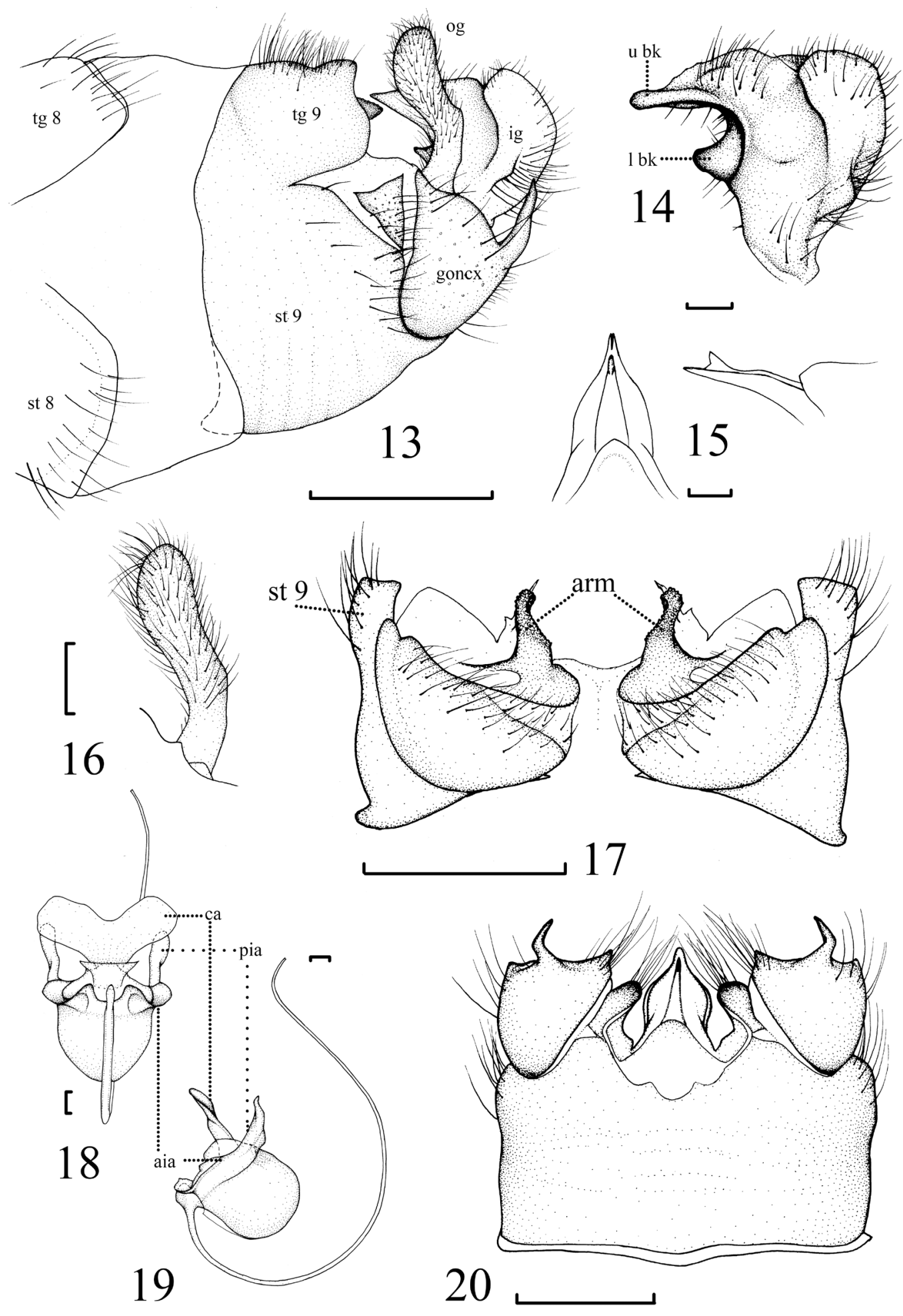

Figs 13-20. Tipula (Vestiplex) uncinella sp. nov., holotype, $\widehat{\jmath}$ (CAU). 13. Hypopygium, lateral view. 14. Inner gonostylus, lateral external view. 15. Adminiculum, ventral view and oblique view. 16. Outer gonostylus, lateral external view. 17. Tergite nine, dorsal view. 18-19. Semen pump, lateral view and dorsal view. 20. Hypopygium, ventral view. Abbreviations: see Material and methods. Scale bars: 13, $17,20=0.5 \mathrm{~mm} ; 14-16,18-19=0.1 \mathrm{~mm}$. 
Tipula (Vestiplex) nayogabuensis sp. nov.

Tipula (Vestiplex) zayulensis Alexander, 1963

Tipula (Vestiplex) nayogabuensis sp. nov. urn:1sid:zoobank.org:act:D91DF543-8018-4FD5-8E99-DCB2AAF3E8FF

Figs 21-29, 86

\section{Diagnosis}

Vertex brownish black, relatively protruded. Prescutum virtually brownish black, black stripes distinct, all stripes with dark black margins. Scutum virtually brownish black. Scutellum dark yellow with brownish black mid-longitudinal stripe. Mediotergite reddish dark brown, dried with pale gray pruinescence and black mid-longitudinally. Thoracic pleuron dark brown with pale gray pruinescence. Posterior margin of tergite 9 with long setae, pair of weak arms arising from ventral surface of tergite 9 , slender hidden bridge between them.

\section{Etymology}

The species is named after the type locality Nayogabu Snow Mountain.

\section{Material examined}

\section{Holotype}

CHINA • O'; Tibet, Bomi, Yigong; 30¹6'19" N, 94²8'28" E; 2290 m a.s.1.; 7 May 2017; Qicheng Yang leg.; light trap; CAU.

\section{Paratypes}

CHINA $\bullet 8 \hat{\partial}$; ; same collection data as for holotype; CAU.

\section{Description}

Male

MeAsurements. Body length $16.5-18.5 \mathrm{~mm}$, wing length $20-22.0 \mathrm{~mm}$, antenna length $4.5 \mathrm{~mm}(\mathrm{n}=9)$.

HeAd (Figs 21, 23). Mainly brownish yellow. Occipital mark dark brown, vertex brownish black, relatively protruded. Rostrum and nasus dark yellow, nasus relatively long. Setae on head dark brown. Scape dark yellow, pedicel pale yellow, flagellum brownish black except first flagellar segment yellowish brown. Proboscis and palpus yellowish gray.

THORAX (Figs 21-23). Mainly dark brown, heavily pale gray pruinescence. Pronotum brown with yellow setae. Prescutum virtually brownish black, black stripes distinct, all stripes with dark black margin. Scutum virtually brownish black. Scutellum dark yellow with brownish black mid-longitudinal stripe. Mediotergite reddish dark brown, dried with pale gray pruinescence and black mid-longitudinally. Thoracic pleuron dark brown with pale gray pruinescence. Parascutellum dark brown. Meron brown. Setae on thorax pale yellow. Legs with coxae and femora yellow, femora with brownish black apexes; tibiae and tarsi dark brown. Setae on legs dark brown. Wing variegated brown; pterostigma brown; petiole of cell $\mathrm{m}$ distinctly shorter than discal cell (Fig. 24). Halter with stem yellow, knob dark brown.

AвDomen (Figs 21, 23). Mainly yellow. Abdominal tergites each with three stripes, middle stripe of tergites 1-2 brownish black, wide, others brown; bilateral stripes black. Abdominal segments 6-9 dark black. Setae on abdomen yellow. 


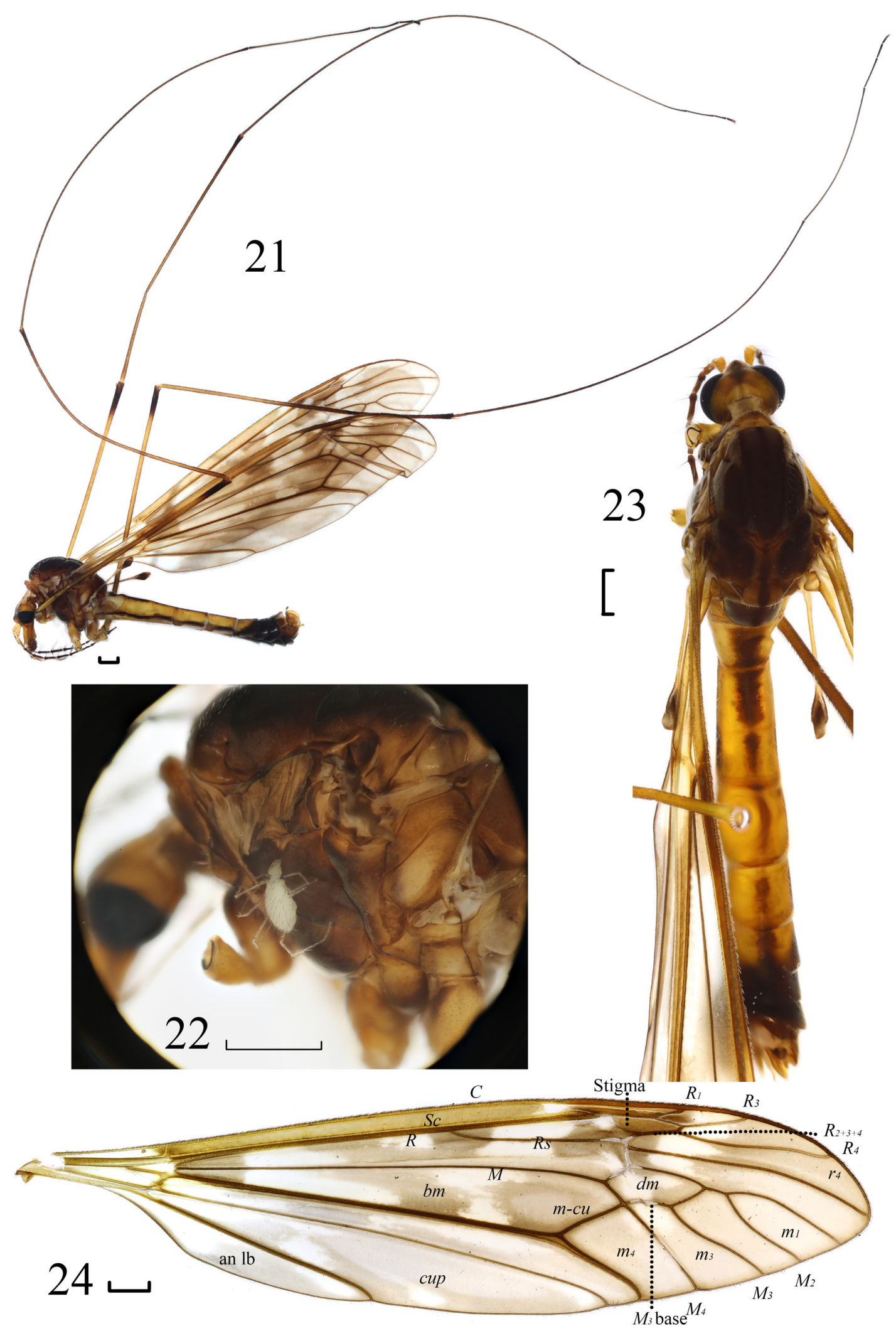

Figs 21-24. Tipula (Vestiplex) nayogabuensis sp. nov., holotype, ô (CAU). 21. Habitus, lateral view. 22. Parasitic mites. 23. Habitus, dorsal view. 24. Wing. Abbreviations: see Material and methods. Scale bars $=1.0 \mathrm{~mm}$. 

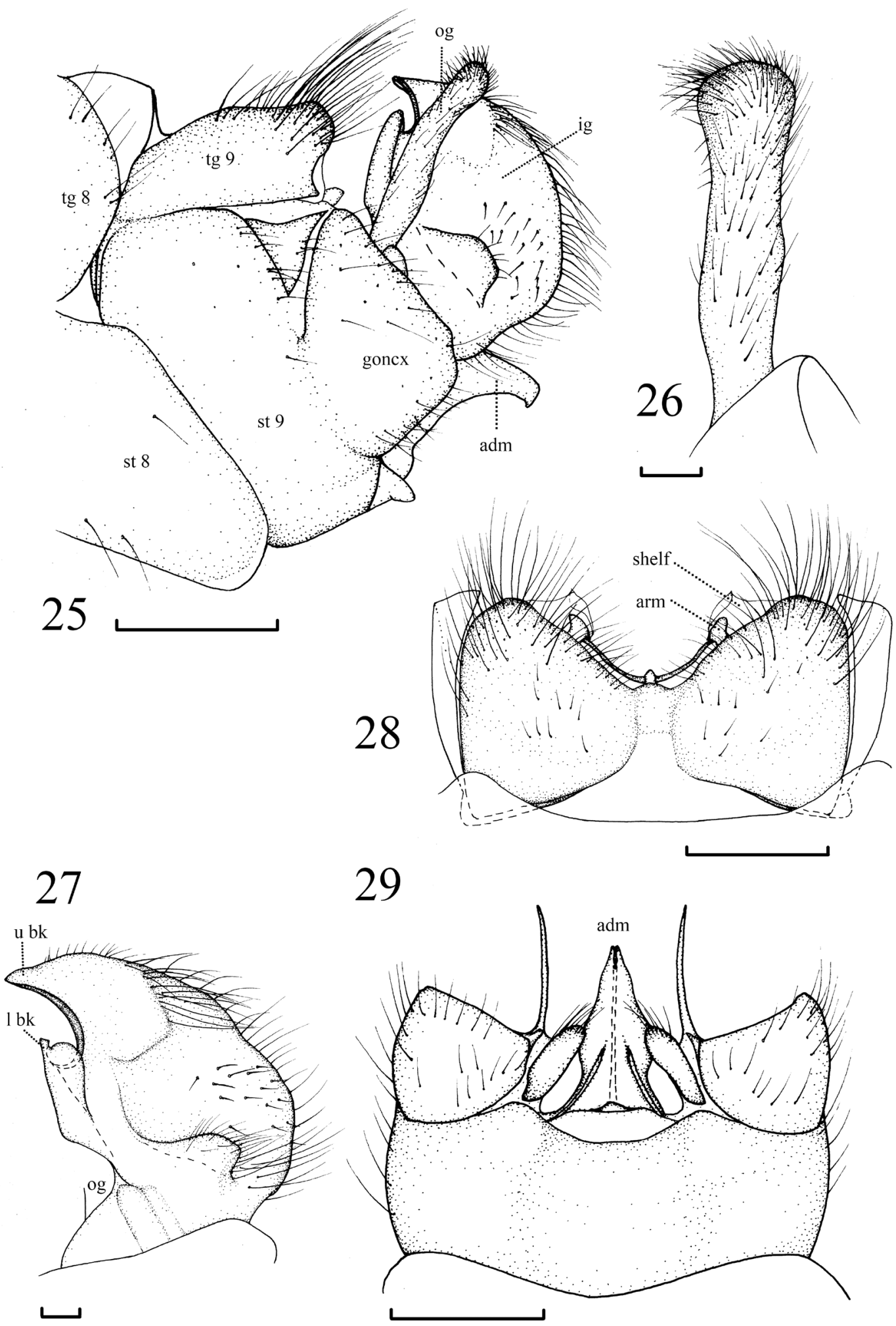

Figs 25-29. Tipula (Vestiplex) nayogabuensis sp. nov., holotype, đ̊ (CAU). 25. Hypopygium, lateral view. 26. Outer gonostylus, lateral external view. 27. Inner gonostylus, lateral external view. 28. Tergite nine, dorsal view. 29. Hypopygium, ventral view. Abbreviations: see Material and methods. Scale bars: $25,28-29=0.5 \mathrm{~mm} ; 26-27=0.1 \mathrm{~mm}$. 
HyPOPYGIUM (Figs 25-29). Gonocoxite hardly elongated, unseparated from sternite 9. Tergite 9 longitudinally divided into two parts, posterior margin with long setae, a pair of weak arms arising from ventral surface of tergite 9, a slender hidden bridge between them (Fig. 28). Appendages of sternite 9 slender (Fig. 29). Apex and middle of outer gonostylus slightly wide (Fig. 26). Inner gonostylus with concavity at middle, posterior part with many bristles, lower margin with bristled raise; base of lower beak inward-rolled, enwrapped black lower beak; upper beak yellow, lower margin black, base with a slight raise (Fig. 27). Apex of adminiculum hooked.

\section{Female}

Unknown or unrecognized.

\section{Distribution}

China: Tibet.

\section{Remarks}

The new species is similar to $T$. (V.) zayulensis from Chayu (= Zayu) of Tibet, but the latter differs in the following characters: prescutum and scutum yellowish brown; thoracic pleuron brownish yellow; all sterno-pleurite with dark brown margin. The outer gonostylus is different from that of $T$. (V.) nayogabuensis sp. nov.

\section{Tipula (Vestiplex) zayulensis Alexander, 1963}

Figs 30-38

Tipula (Vestiplex) zayulensis Alexander, 1963: 328. Type locality: China: Tibet, Zayul.

\section{Diagnosis}

Occipital stripe dark brown, middle wide, anterior part extended to vertex. All sterno-pleurites with dark brown margins. Tergite 9 longitudinally divided into two parts, posterior margin with long setae, and a bridge between them, a pair of angular arms arising from ventral surface of tergite 9 . Inner gonostylus with concavity at middle, concavity with many bristles, lower margin of concavity with bristled raise; base of inner gonostylus inward-rolled, enwrapped black and swollen lower beak; upper beak relatively obtuse, slightly recurved.

\section{Material examined}

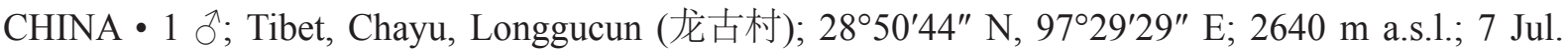

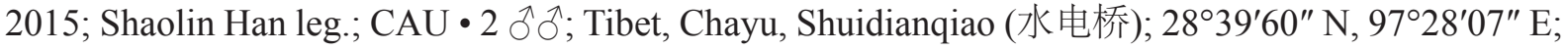
2640 m a.s.l.; 12 Jun. 2019; Qicheng Yang leg.; sweeping net; CAU • 1 ô; Tibet, Chayu County; $28^{\circ} 39^{\prime} 49^{\prime \prime}$ N, 97²7'52" E; 2337 m a.s.1.; Jun. 2020; Hui Wang leg.; CAU.

\section{Redescription}

\section{Male}

Measurements. Body length $18.5 \mathrm{~mm}$, wing length $20.0 \mathrm{~mm}$, antenna length $4.0 \mathrm{~mm}(\mathrm{n}=3)$.

HeAd (Figs 30, 32). Mainly yellow. Occipital stripe dark brown, middle wide, anterior part extended to vertex. Rostrum and nasus yellow, nasus long. Setae on head dark brown. Scape yellow, pedicel pale yellow, flagellum yellowish brown. Proboscis and palpus yellowish dark brown. 

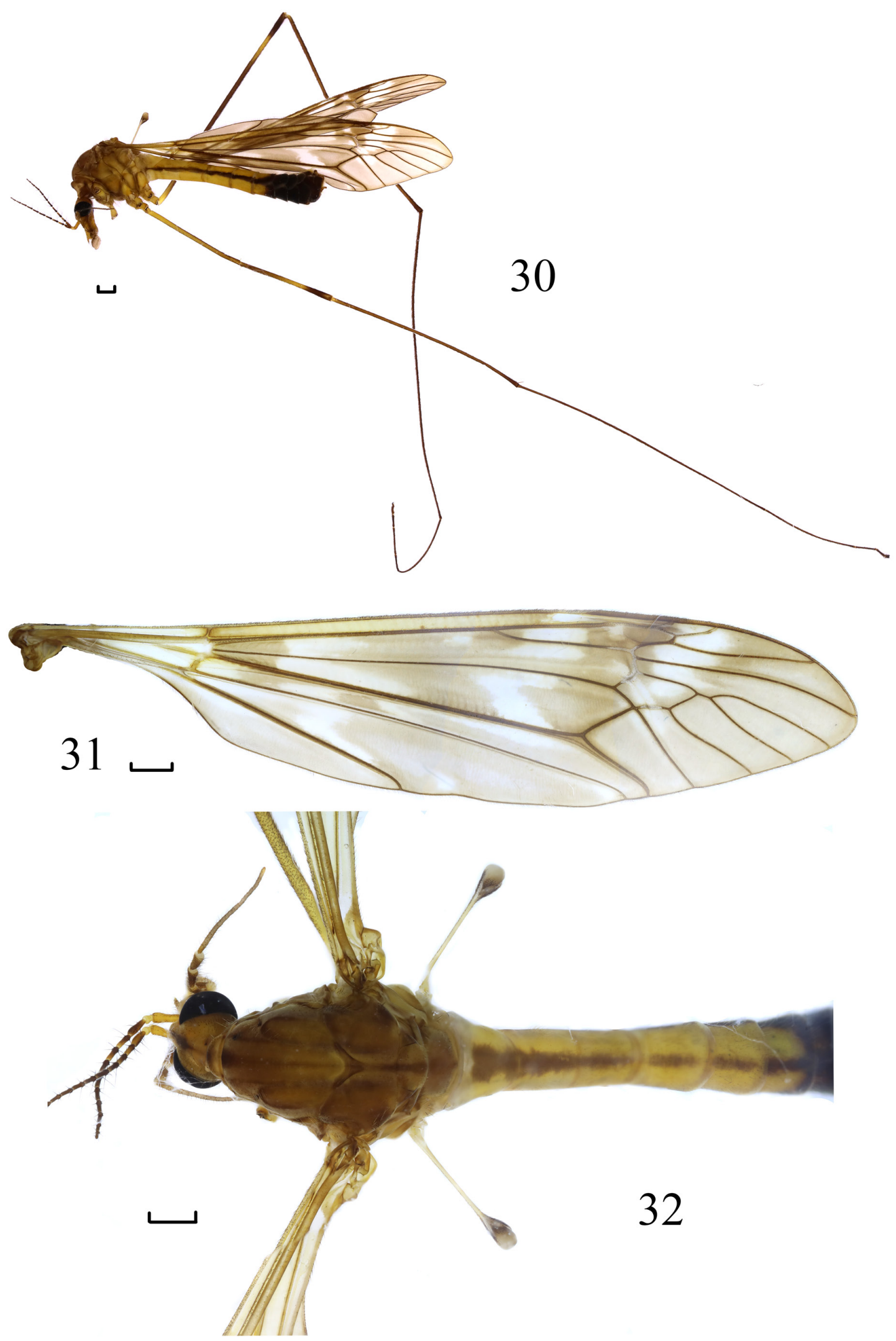

Figs 30-32. Tipula (Vestiplex) zayulensis Alexander, 1963, § (CAU). 30. Habitus, lateral view. 31. Wing. 32. Habitus, dorsal view. Scale bars $=1.0 \mathrm{~mm}$. 


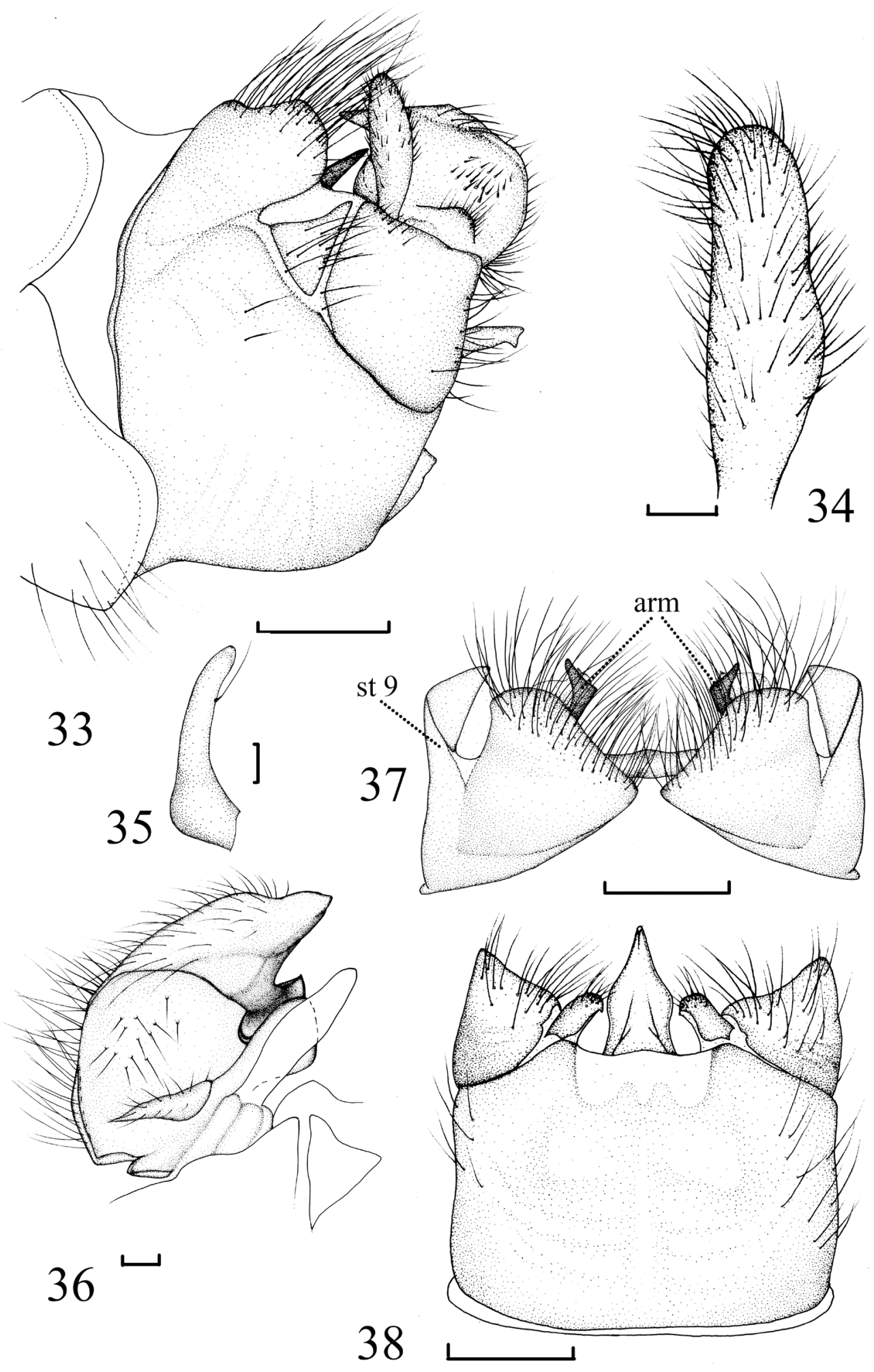

Figs 33-38. Tipula (Vestiplex) zayulensis Alexander, 1963, §̊ (CAU). 33. Hypopygium, lateral view. 34. Outer gonostylus, lateral external view. 35. Appendages of sternite 9, lateral view. 36. Inner gonostylus, lateral external view. 37. Tergite nine, dorsal view. 38. Hypopygium, ventral view. Abbreviations: see Material and methods. Scale bars: $33,37-38=0.5 \mathrm{~mm} ; 34-36=0.1 \mathrm{~mm}$. 
Thorax (Figs 30, 32). Mainly brownish yellow, heavily gray pruinescence. Pronotum yellowish brown, middle and both side each with brown spot. Prescutum yellowish brown with four brown stripes, all stripes with dark brown margins. Scutum yellowish brown with four dark brown spots. Scutellum yellowish brown with dark brown mid-longitudinal stripe. Mediotergite brown with dark brown midlongitudinal stripe. Thoracic pleuron brownish yellow. All sterno-pleurite with dark brown margins. Setae on thorax yellow. Legs with coxae yellow, femora with dark brown tips; tibiae and tarsi dark brown. Setae on legs dark brown. Wing variegated pale brown; pterostigma brown; petiole of cell $\mathrm{m}_{1}$ distinctly shorter than discal cell (Fig. 31). Halter with stem yellow, knob greyish black.

ABdomen (Figs 30, 32). Mainly yellow. Abdominal tergites each with three stripes, middle stripe brown, bilateral stripes black. Abdominal segments 6-9 dark black. Setae on abdomen brownish yellow.

Hypopygium (Figs 33-38). Gonocoxite slightly elongated, separated from sternite 9. Tergite 9 longitudinally divided into two parts, posterior margin with long setae, and a bridge between them, a pair of angular arms arising from ventral surface of tergite 9 . Sternite 9 with a pair of very short appendages, as shown in figure, with a long seta (Fig. 35), covered by inner gonostylus and not visible in the lateral external view. Outer gonostylus relatively small, posterior margin basally slightly wide (Fig. 34). Inner gonostylus with concavity at middle, concavity with many bristles, lower margin with bristled raise; base of inner gonostylus inward-rolled, enwrapped black and swollen lower beak; upper beak relatively obtuse, slightly recurved (Fig. 36).

\section{Female}

Described by Alexander (1963).

\section{Distribution}

China: Tibet.

Tipula (Vestiplex) himalayensis group in Tibet

Tipula (Vestiplex) alyxis Alexander, 1963

Tipula (Vestiplex) bucera sp. nov.

Tipula (Vestiplex) himalayensis Brunetti, 1911

Tipula (Vestiplex) nigroapicalis Brunetti, 1911

Tipula (Vestiplex) bucera sp. nov. urn:1sid:zoobank.org:act:4AB06AB7-6108-40AF-A8C8-CAEDF0226964

Figs 39-50, 84, 86

\section{Diagnosis}

Scape and pedicel yellow, first flagellar segment dark yellow, other flagellar segments bicolor, yellowish with dark brown base. Scutellum and mediotergite dark yellow. Gonocoxite elongated, separated from sternite 9, posterior margin with an unusually strong black spine, bent inward and horn-like.

\section{Etymology}

The species is named after the shape of gonocoxite, the Latin adjective 'bucera' means 'ox-horned'.

\section{Material examined}

\section{Holotype}

CHINA • $\mathrm{O}^{\top}$; Tibet, Bomi, Yigong; 30¹6'19" N, 9448'28" E; 2240 m a.s.1.; 7 Jun. 2017; Qicheng Yang leg.; light trap; CAU. 

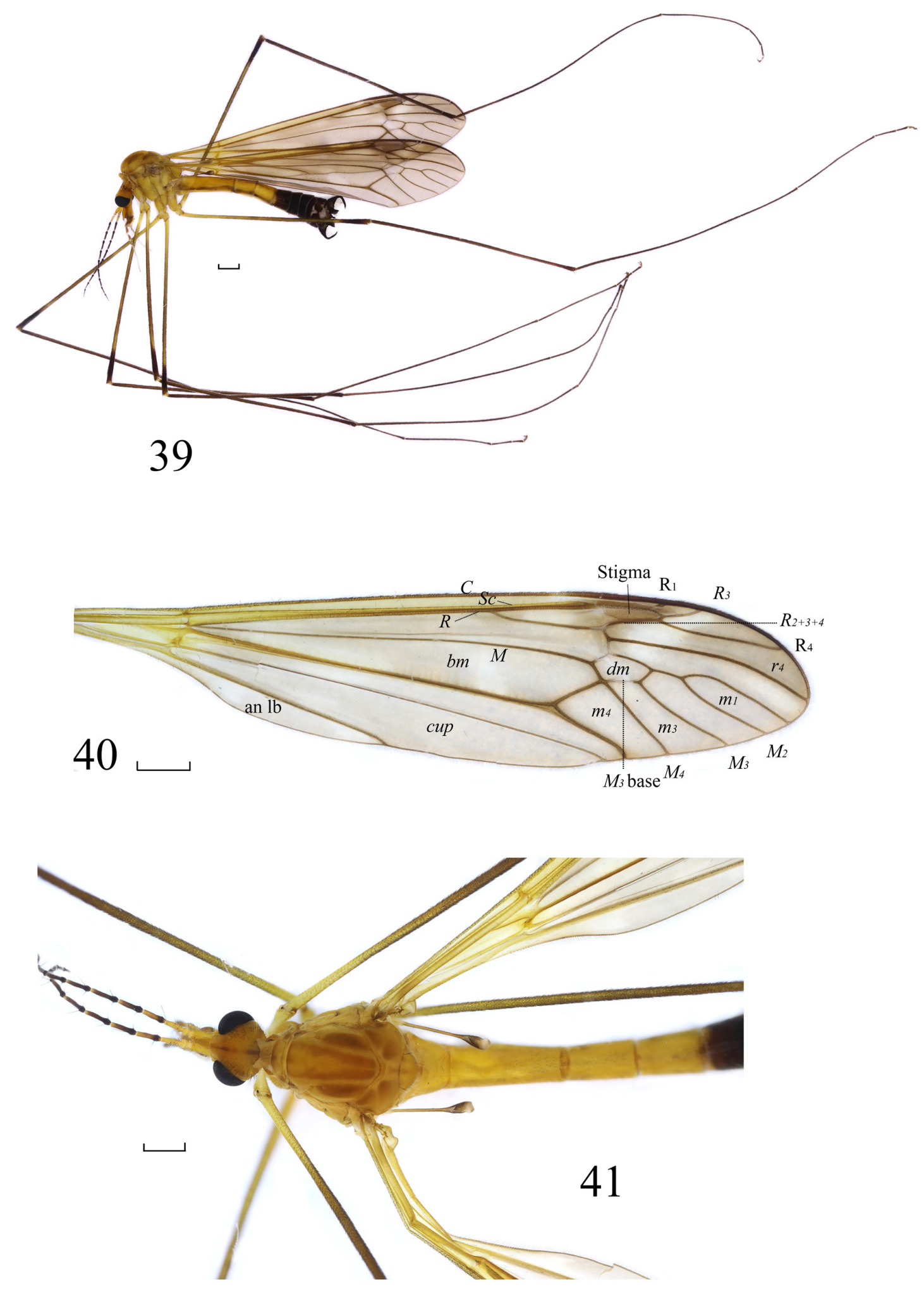

Figs 39-41. Tipula (Vestiplex) bucera sp. nov., holotype, $ð$ (CAU). 39. Habitus, lateral view. 40. Wing. 41. Habitus, dorsal view. Abbreviations: see Material and methods. Scale bars $=1.0 \mathrm{~mm}$. 

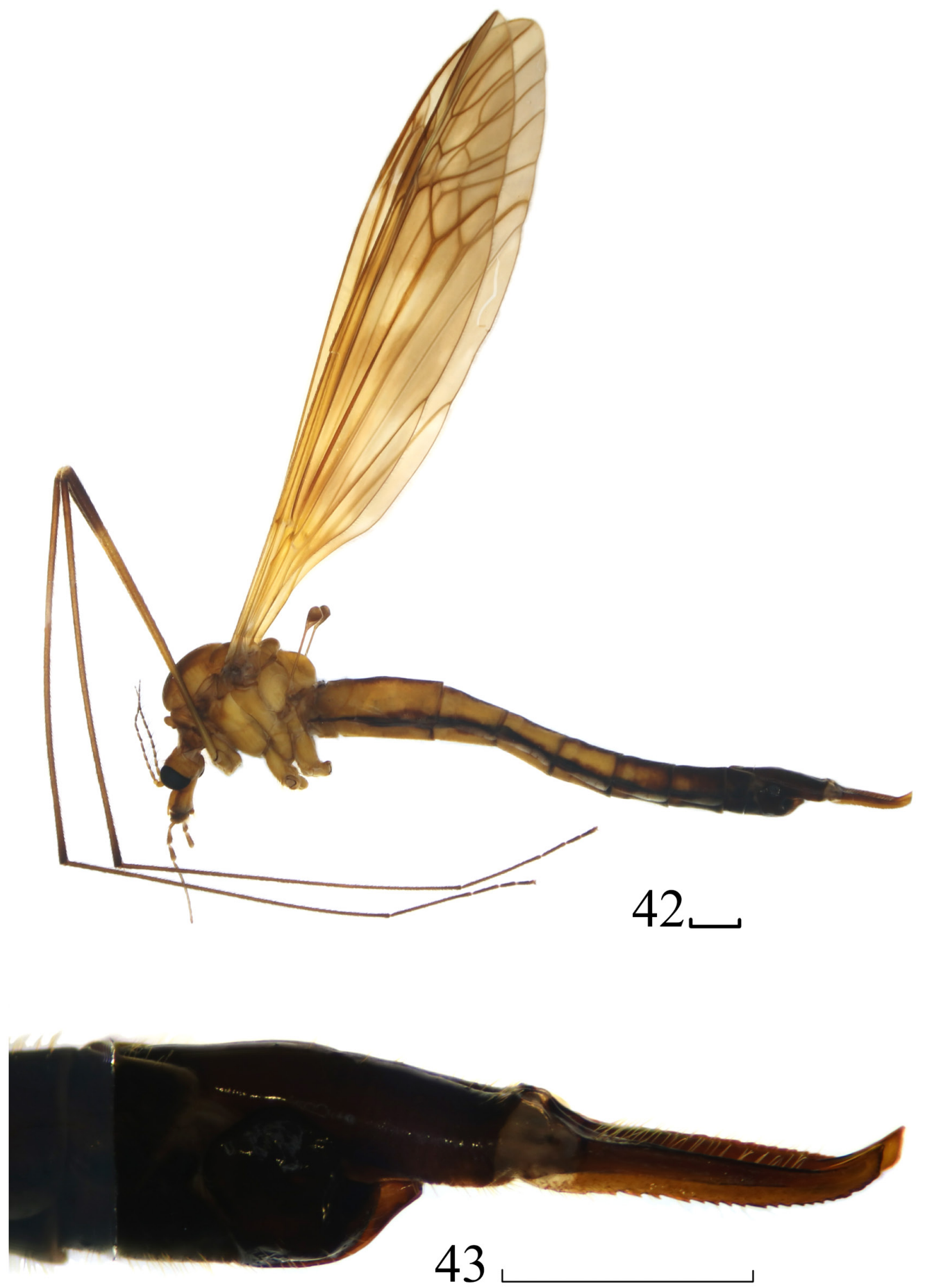

Figs 42-43. Tipula (Vestiplex) bucera sp. nov., allotype, $q$ (CAU). 42. Habitus, lateral view. 43. Ovipositor, lateral view. Scale bars $=1.0 \mathrm{~mm}$. 


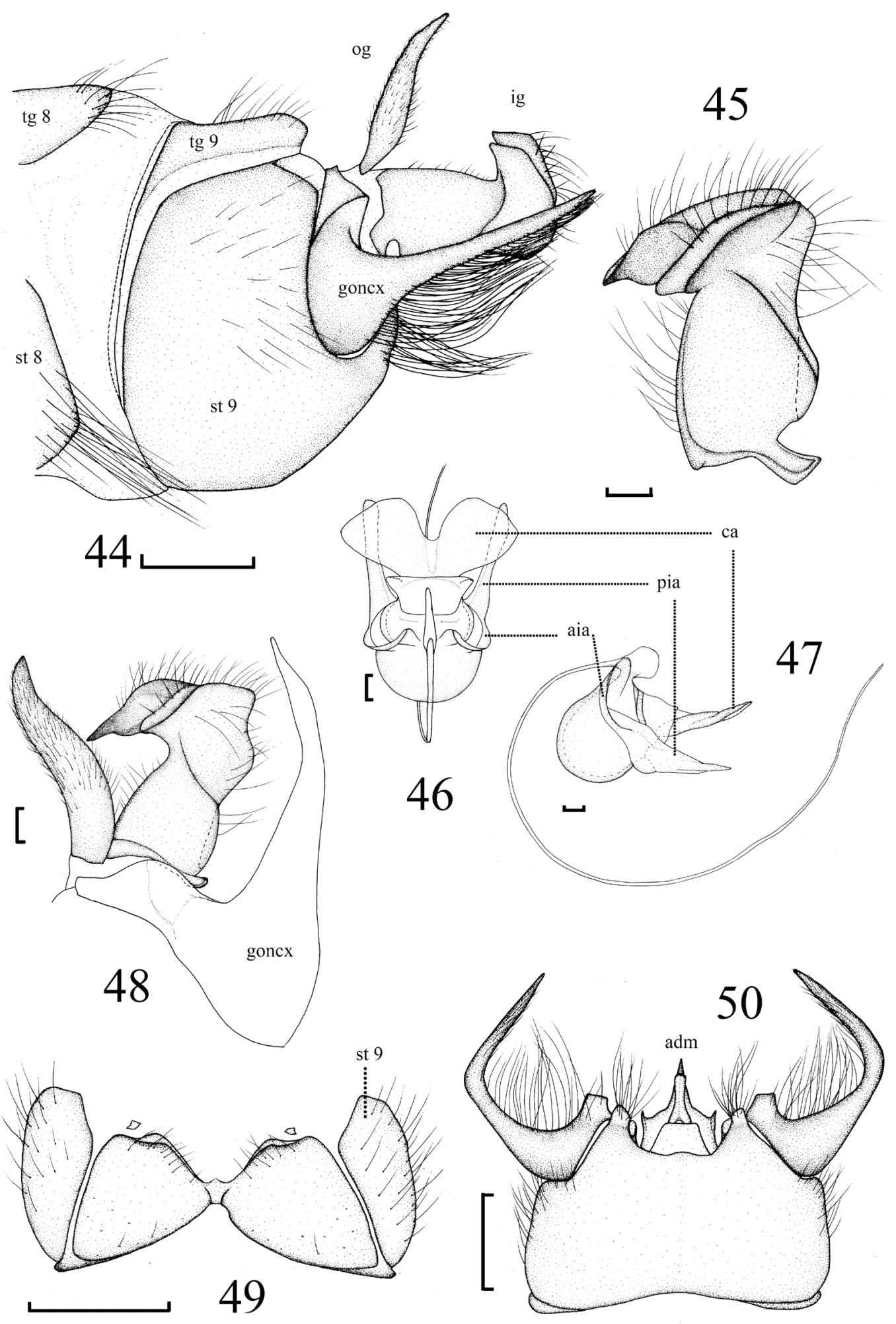

Figs 44-50. Tipula (Vestiplex) bucera sp. nov., holotype, ô (CAU). 44. Hypopygium, lateral view. 45. Inner gonostylus, lateral external view. 46-47. Semen pump, lateral view and dorsal view. 48. Outer and inner gonostylus, lateral external view. 49. Tergite nine, dorsal view. 50. Hypopygium, ventral view. Abbreviations: see Material and methods. Scale bars: 44, 49-50 $=0.5 \mathrm{~mm} ; 45-48=0.1 \mathrm{~mm}$. 


\footnotetext{
Allotype

CHINA • $q$; same collection data as for holotype; CAU.

Paratypes

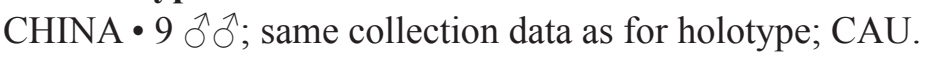

\section{Description}

\section{Male}

Measurements. Body length $13.0 \mathrm{~mm}$, wing length $15.0 \mathrm{~mm}$, antenna length $4.5 \mathrm{~mm}(\mathrm{n}=10)$.

HeAD (Figs 39, 41). Mainly yellow. Occipital stripe dark brown, with brown setae. Rostrum and nasus yellow, rostrum with brown setae and nasus with dark yellow setae. Scape and pedicel yellow, first flagellar segment dark yellow, other flagellar segments bicolor yellowish with dark brown base. Proboscis and palpus grayish yellow.

Thorax (Figs 39, 41). Mainly yellow, heavily pruinose. Pronotum yellow with yellow setae. Prescutum with four yellowish gray stripes, median stripe broadened apically and gradually narrowing to base, lateral stripes long-oval. Scutum yellow with four yellowish gray spots. Scutellum and mediotergite dark yellow. Thoracic pleuron yellow. Parascutellum pale yellow. Meron yellow. Setae on thorax yellow. Legs with coxae and femora yellow, femora with dark brown apices and brown middle parts; tibiae and tarsi dark brown. Setae on legs dark brown. Wing light brown; pterostigma brown; petiole of cell $\mathrm{m}_{1}$ and discal cell almost equilong (Fig. 40). Halter with stem brown, knob dark brown with pale tip.

AвDomen (Figs 39, 41). Mainly yellow. Abdominal tergites each with three stripes, middle stripe pale gray, lateral stripes brown. Abdominal segments 5-9 black. Setae on abdomen brownish yellow.

Hypopygium (Figs 44-45, 48-50). Gonocoxite elongated, separated from sternite 9, gonocoxite ends with an unusually strong black spine, bent inward and horn-like, ventral of spine with long setae, basal setae longest and decreases to tip, curl inward. Tergite 9 longitudinally divided into two parts, slightly connected. Sternite 9 with a median prominence, adminiculum with a pair of sharp projections on both sides. Outer gonostylus black with yellow bristles, bent, willow leaf shaped (Figs 44, 48). Inner gonostylus with a slanted bar like raise; upper beak sharp, curled inward (Figs 45, 48). Semen pump (Figs 46-47) as shown in figures. Aedeagus with a sclerotized suborbicular appendage at base.

\section{Female}

MeAsurements. Body length $17.5 \mathrm{~mm}$, wing length $17 \mathrm{~mm}$, antenna length $3 \mathrm{~mm}(\mathrm{n}=1)$.

Coloration. Body color slightly darker than male. Antenna relatively shorter than male. Scape and pedicel yellow, flagellar segments 1-4 bicolor yellow with pale brown base, other segments pale brown. Brown and black part of legs paler than male. Wing same as male except knob of halter without pale tip. Abdominal tergites each with three stripes, middle stripe brown, lateral stripes black, abdominal segments 5-7 yellowish brown, and brown gradually deepened, $8^{\text {th }}$ segment dark brown. Other characteristics as in male (Fig. 42).

Ovipositor. Tergite 9 dark brown, tergite 10 shining reddish brown. Cercus brown, tip slightly upturned, outer margin with rough serration (Fig. 43).

\section{Distribution}

China (Tibet). 


\section{Remarks}

The new species is similar to T. $(V$.) coxitalis Alexander, 1935 from Anhui and Taiwan, China, but the latter differs in the following characters: gonocoxite ends with a slightly twisted spine; outer gonostylus narrow, filiform; inner gonostylus without slanted bar-like raise; sternite 9 near caudal end on either side of midline with a conspicuous hair pencil of reddish bristles, these pencils not arising from basal tubercles (Men 2015). This species is similar to $T$. ( $V$.) bicalcarata Savchenko, 1965 and $T$. (V.) maoershanensis Men \& Young, 2017, but the outer gonostylus of the latter is not willow leaf shaped. The posterior margin of inner gonostylus with a finger-like protrusion (Men et al. 2017).

Tipula (Vestiplex) himalayensis Brunetti, 1911

Figs 51-57, 86

Tipula himalayensis Brunetti, 1911: 252. Type locality: India: Darjeeling.

Tipula (Vestiplex) subreposita Alexander, 1942: 39. Type locality: India: Darjiling, Mangpu.

Tipula himalayensis - Edwards 1924: 305.

Tipula (Vestiplex) himalayensis - Alexander 1942: 41; 1963: 325. — Joseph 1974: 269. — Starkevich \& Podenas 2011: 276. — Starkevich 2012: 75. — Pilipenko et al. 2019: 10.

\section{Diagnosis}

Scape yellow, pedicel pale yellow, first flagellar segment yellowish brown, other flagellar segments dark brown. Middle of abdominal tergites 2-4 with pale brown spots, both sides each with brown stripe. Gonocoxite strongly elongated. Outer gonostylus brownish black, without setae except margins of apex and base with few setae. Inner gonostylus with upper beak bearing born-like elevation.

\section{Material examined}

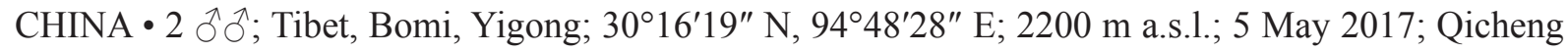
Yang leg.; light trap; CAU.

\section{Redescription}

\section{Male}

Measurements. Body length $15.0 \mathrm{~mm}$, wing length $17.0 \mathrm{~mm}$, antenna length $4.0 \mathrm{~mm}(\mathrm{n}=2)$.

HeAd (Figs 51, 53). Mainly reddish yellow. Vertex with brown stripe. Rostrum and nasus dark yellow. Setae on head dark brown. Scape yellow, pedicel pale yellow, first flagellar segment yellowish brown, other flagellar segments dark brown. Proboscis and palpus brownish yellow.

Thorax (Figs 51, 53). Mainly dark yellow, heavily pruinose. Pronotum dark yellow with dark yellow setae, middle pale brown and both sides with a pale brown spot. Prescutum dark yellow with four reddish brown stripes, median stripes broadened apically and gradually narrowing to base. Scutum with four reddish brown spots. Scutellum yellow with black mid-longitudinal stripe. Mediotergite yellow. Thoracic pleuron reddish yellow. Setae on thorax yellow. Legs with coxae and femora yellow, femora with brownish black apices and middle portions, tibiae and tarsi brownish black. Setae on legs brownish black. Wing light brown; pterostigma pale brown; petiole of cell $\mathrm{m}_{1}$ slightly shorter than discal cell (Fig. 52). Halter with stem yellow, knob pale yellow.

Aвdomen (Figs 51, 53). Mainly yellow. Middle of abdominal tergites 2-4 with pale brown sports, both sides each with a brown stripe. Abdominal segment 5 yellowish brown, segments 6-9 brownish black. Setae on abdomen yellow. 


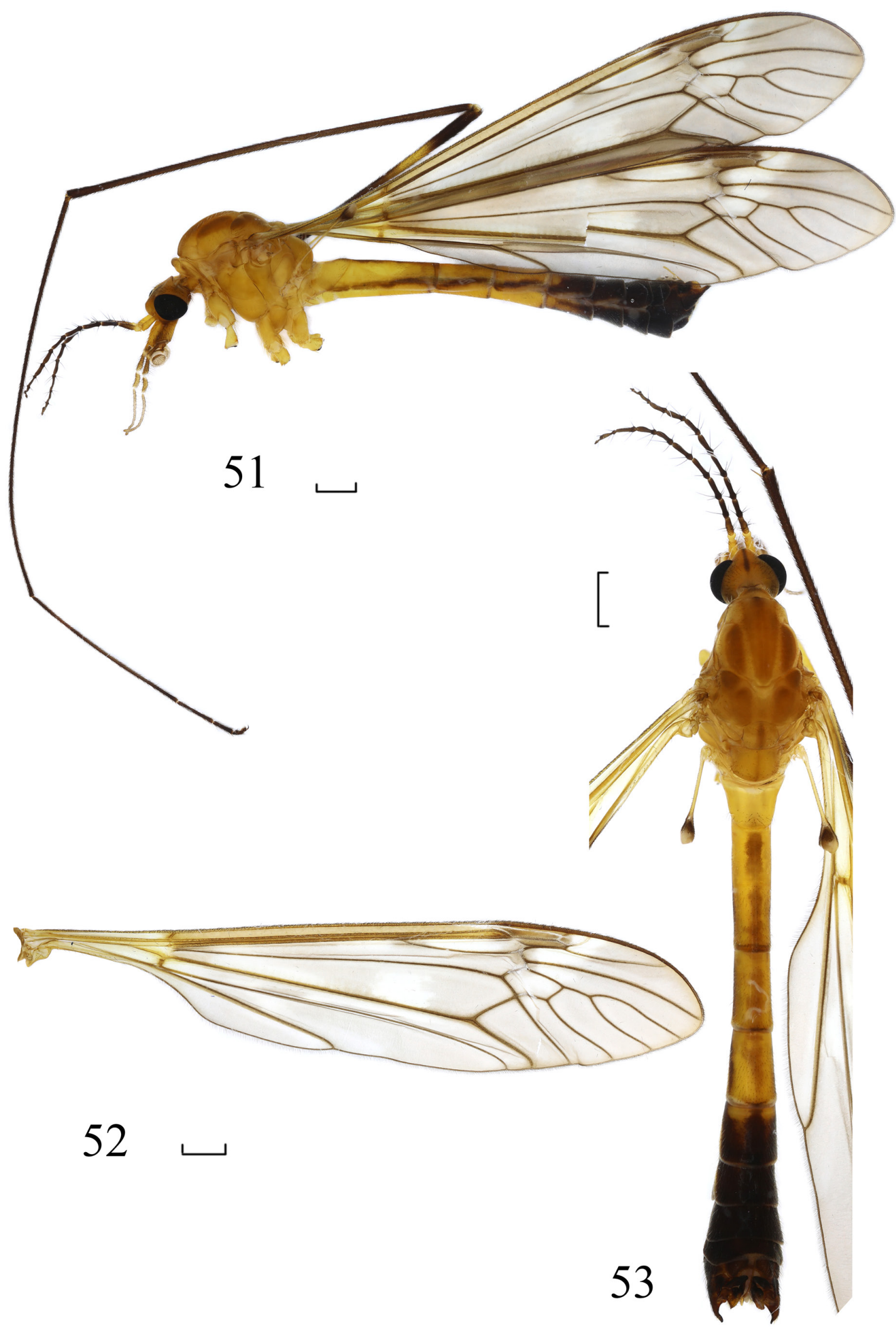

Figs 51-53. Tipula (Vestiplex) himalayensis Brunetti, 1911, ô (CAU). 51. Habitus, lateral view. 52. Wing. 53. Habitus, dorsal view. Scale bars $=1.0 \mathrm{~mm}$. 


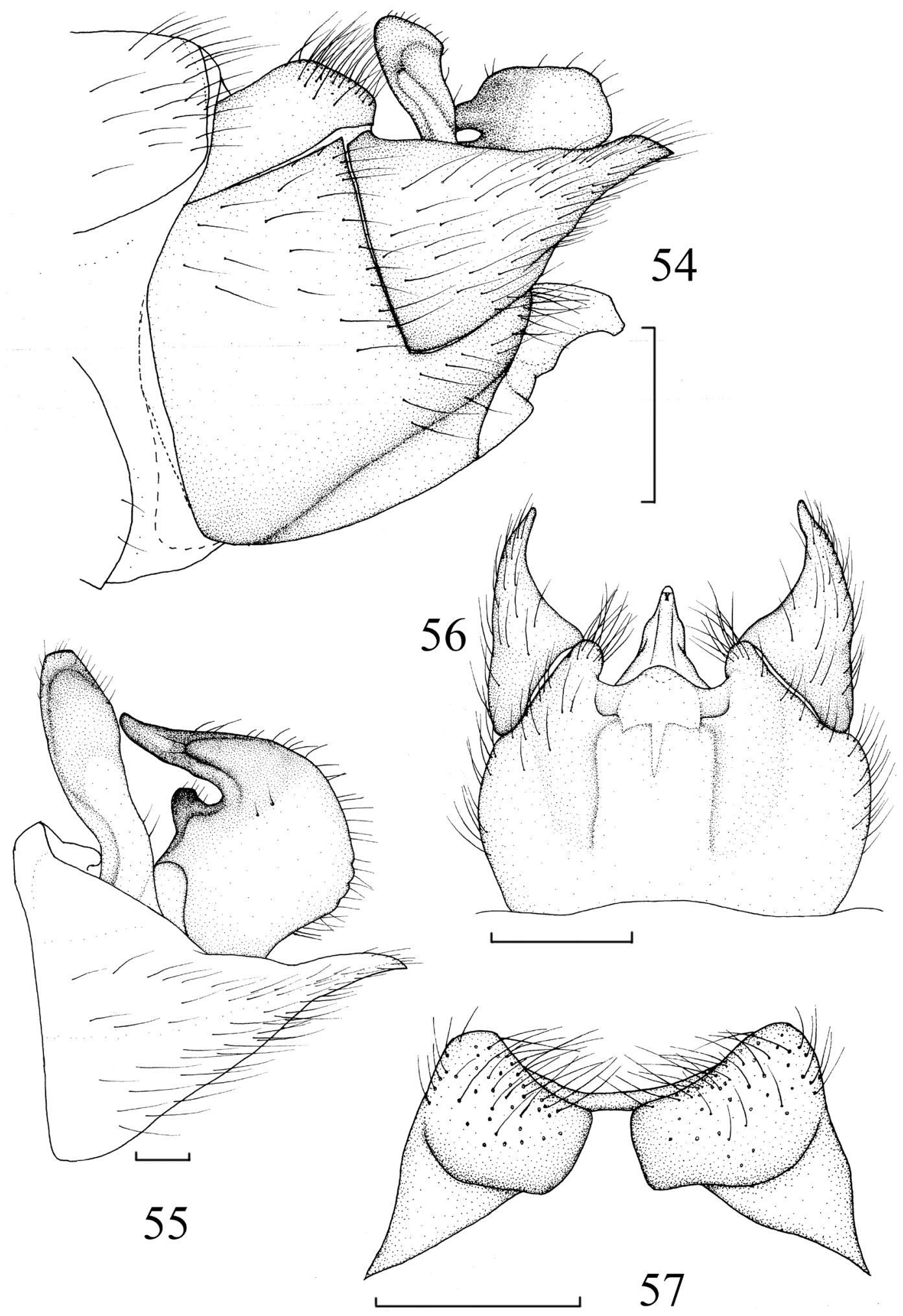

Figs 54-57. Tipula (Vestiplex) himalayensis Brunetti, 1911, § (CAU). 54. Hypopygium, lateral view. 55. Outer and inner gonostylus, lateral external view. 56. Hypopygium, ventral view. 57. Tergite nine, dorsal view. Scale bars: $54,56-57=0.5 \mathrm{~mm} ; 55=0.1 \mathrm{~mm}$. 
Hypopygium (Figs 54-57). Gonocoxite strongly elongated, thick, separated from sternite 9. Tergite 9 longitudinally divided into two parts, a bridge present between them. Sternite 9 with a median prominence. Outer gonostylus sclerotized, brownish black, without setae except margins of apex and base with few setae. Inner gonostylus with setae dorsally; upper beak with a horn-like elevation bearing 2 setae at tip, base of upper beak with 2 distinct setae; inner gonostylus with setae dorsally (Fig. 55).

\section{Female}

See Brunetti (1911).

\section{Distribution}

China (Tibet, Yunnan); India (Assam, Himachal Pradesh, Sikkim, Uttarakhand, Uttar Pradesh, W Bengal); Myanmar; Vietnam.

\section{Remarks}

Here, we add new distributional data and new illustrations. Yigong Township is now the current northernmost distribution of $T$. $(V$.) himalayensis. The species was considered by Brunetti to be variable but within certain limits and can be easily recognized by the pale yellow wide ring on all the femora about as far from the tip as the width of the ring. We examined other additional material, in addition to the previously indicated: 1 (paratype) Darjiling; 6000 feet a.s.1.; 22 Sep. 1908; Brunetti (USNM) / $1 \hat{\delta}$ (syntype) Darjiling; 20 Oct. 1905; Brunetti (BMNH(E)\#246064). There is no difference in the characteristics of the femora of the three, but the wing veins are slightly different. It seems that the difference in the wing veins shown in Joseph's illustrations (Joseph 1974) can be regarded as intraspecific variation. But there are also some differences in the shape of inner gonostylus as shown in the illustrations, especially the beak different from others. It is necessary to make further observations on the specimens of ZSI.

Tipula (Vestiplex) nigroapicalis Brunetti, 1911 Figs 58-65

Tipula nigroapicalis Brunetti, 1911: 257. Type locality: India: Darjiling. Tipula lepcha Alexander, 1958: 151. Type locality: Nepal: Simbhanjang Pass.

Tipula nigroapicalis - Edwards 1928: 692.

Tipula (Vestiplex) nigroapicalis - Alexander 1953: 342; 1968: 91. — Pilipenko et al. 2019: 10. Tipula lepcha-Alexander 1960: 144.

\section{Diagnosis}

Occipital stripe dark brown. Rostrum brownish yellow, nasus brown with yellow setae. Scape brownish yellow and pedicel pale yellow, first flagellar segment brownish yellow, other flagellar segments black. Scutum yellow with four brownish black spots, which are virtually confluent on each side, anterior two spots small; all spots with olive-gray pruinescence. Upper part of fore coxa brownish black. Inner gonostylus with upper beak sharp bearing, a semicircular striped raise at base; posterior crest produced backward. Adminiculum with a pair of long projections on both sides, longer than apex of phallic guide.

\section{Material examined}

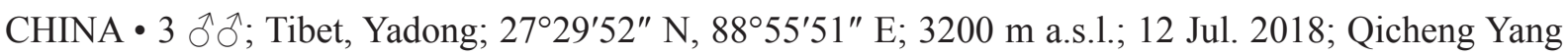
leg.; light trap; CAU. 

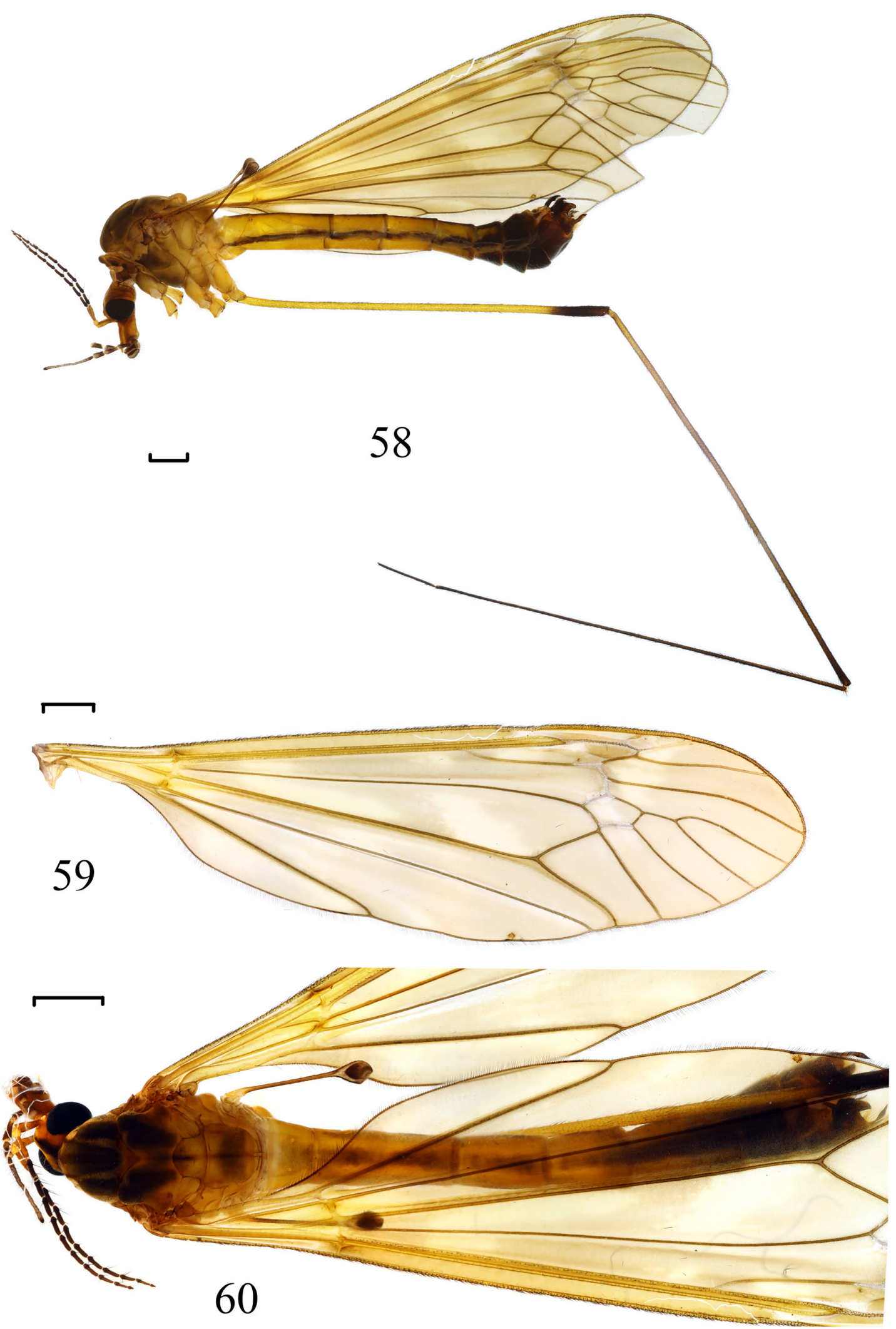

Figs 58-60. Tipula (Vestiplex) nigroapicalis Brunetti, 1911, đ (CAU). 58. Habitus, lateral view. 59. Wing. 60. Habitus, dorsal view. Scale bars $=1.0 \mathrm{~mm}$. 

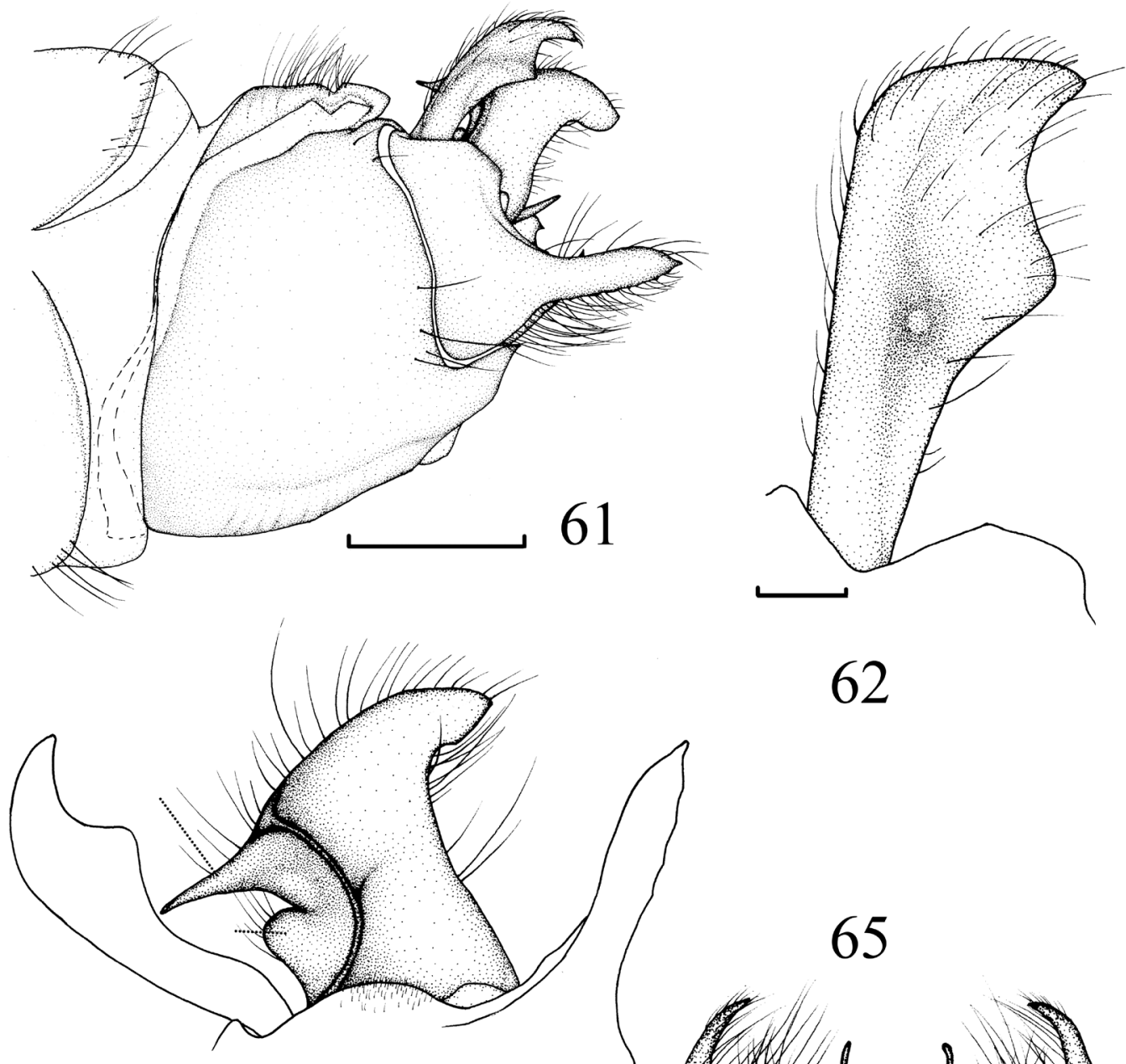

62

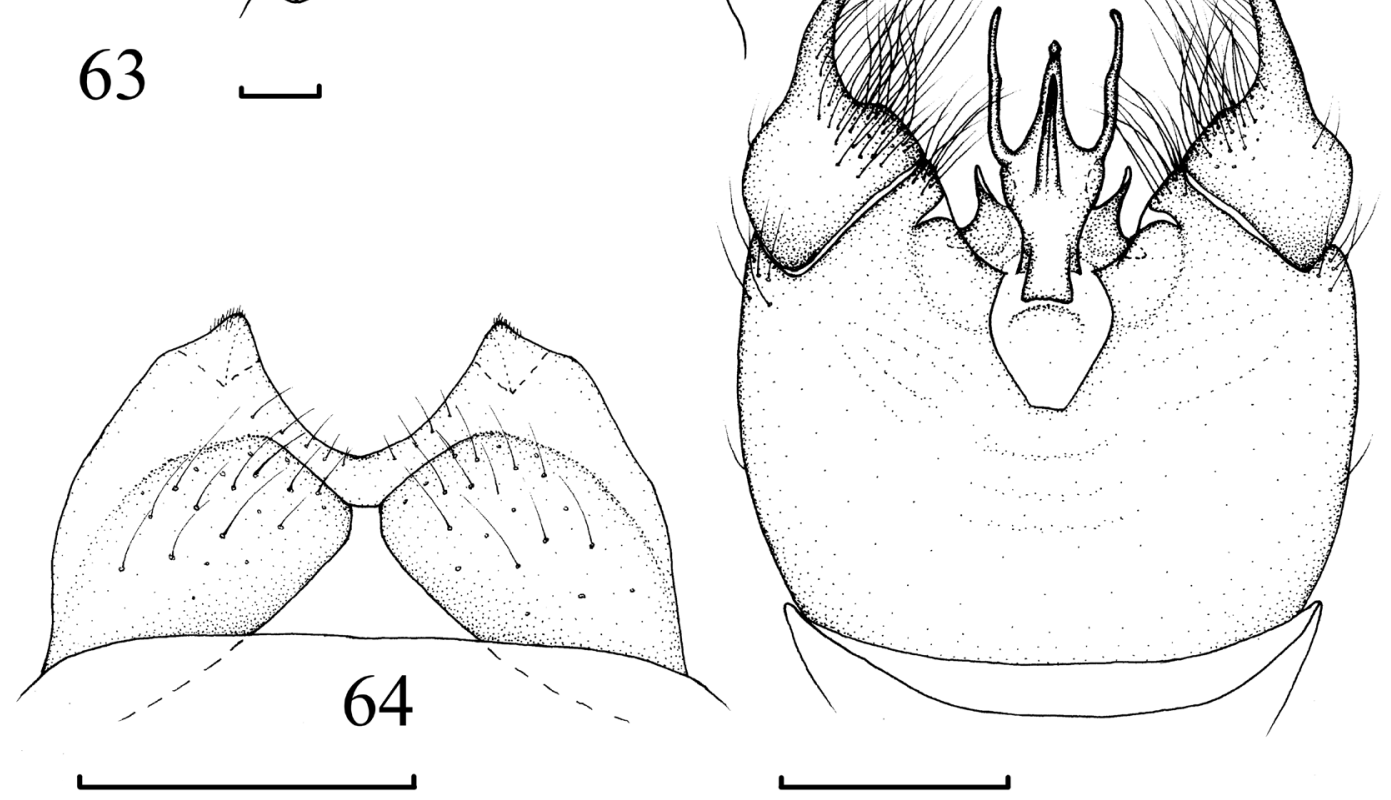

Figs 61-65. Tipula (Vestiplex) nigroapicalis Brunetti, 1911, $ð$ (CAU). 61. Hypopygium, lateral view. 62. Outer gonostylus, lateral external view. 63. Inner gonostylus, lateral external view. 64. Tergite nine, dorsal view. 65. Hypopygium, ventral view. Scale bars: $61,64-65=0.5 \mathrm{~mm} ; 62-63=0.1 \mathrm{~mm}$. 


\section{Redescription}

Male

MeAsurements. Body length 12.0-13.0 mm, wing length $15.0 \mathrm{~mm}$, antenna length $3.0 \mathrm{~mm}(\mathrm{n}=3)$.

HEAD (Figs 58, 60). Mainly brownish yellow. Occipital stripe dark brown. Rostrum brownish yellow, nasus brown with yellow setae. Setae on head brownish black. Scape brownish yellow, pedicel pale yellow, first flagellar segment brownish yellow, other flagellar segments black. Proboscis and palpus black.

THorax (Figs 58, 60). Mainly brownish yellow, heavily yellow and gray pruinescence. Pronotum brownish gray. Prescutum with four dark brownish black stripes, median stripes virtually confluent, broadened apically and gradually narrowing to base, lateral stripes long-oval; all stripes with olive-gray pruinescence. Scutum yellow with four dark brownish black spots, which are virtually confluent on each side, anterior two spots small, all spots with olive-gray pruinescence. Scutellum yellow with dark brown mid-longitudinal stripe. Mediotergite yellow, middlly pale gray with dark brown mid-longitudinal stripe. Scutellum and mediotergite with golden pruinescence. Thoracic pleuron with yellow pruinescence. Anepisternum and katepisternum yellow, each with a brownish black anterior lower spot. Anepimeron yellow with a small brownish black upper spot; katepimeron yellow. Meron yellow with brownish black lower part. Parascutellum yellow. Anatergite and katatergite yellow. Setae on thorax dark yellow. Legs with coxae and femora yellow, except upper part of fore coxa brownish black, femora with black apices; tibiae brownish yellow with black apices; tarsi dark black. Setae on legs black. Wing yellowish brown; pterostigma brown; petiole of cell $\mathrm{m}_{1}$ slightly shorter than discal cell (Fig. 59). Halter with stem brown, knob grayish black with pale gray apex.

Abdomen (Figs 58, 60). Mainly yellow. Abdominal tergites each with three brown stripes, middle stripe pale. Abdominal segments 7-9 brownish black. Setae on abdomen yellow except black setae on middle stripe.

Hypopygium (Figs 61-65). Gonocoxite elongated into dagger-shaped extension, separated from sternite 9. Posterior margin of tergite 9 depressed medially, connected by a short bridge. Sternite 9 , adminiculum trident-shaped, with a pair of long projections on both sides, longer than apex of phallic guide, ventral part of adminiculum with a large projection. Outer gonostylus black, with a central bulge posterior margin bearing subtriangular protrusion (Fig. 62). Inner gonostylus with upper beak sharp, base of beak with a semicircular striped raise; posterior crest produced backward (Fig. 63).

\section{Female}

See Brunetti (1911).

\section{Distribution}

China (Tibet); India (Uttarakhand, W Bengal); Nepal (Simbhanjang Pass).

Tipula (Vestiplex) subtincta group in Tibet

Tipula (Vestiplex) distifurca Alexander, 1942

Tipula (Vestiplex) platyphylla sp. nov.

Tipula (Vestiplex) platyphylla sp. nov. urn:1sid:zoobank.org:act:36161517-739E-408A-8F37-B5161284802B

Figs $66-73$

\section{Diagnosis}

Vertex with brownish black stripe. Scape, pedicel and first flagellar segment yellow, other flagellar segments bicolor, yellowish with dark brown base. Scutellum and mediotergite dark yellow with dark 
gray mid-longitudinally. Prescutum dark yellow with four stripes, median stripes reddish brown, lateral stripes dark. Tergite 9 of male separated medially, with fleshy upper tergal lobes flattened, and two widened black sclerotized blades at a lower level.

\section{Etymology}

The species is named after the shape of blades of tergite 9, the Latin adjective 'platyphylla' refers to 'having flat leaves'.

\section{Material examined}

\section{Holotype}

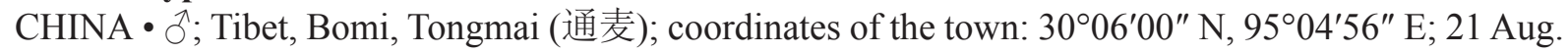
2011; Lihua Wang leg.; light trap; specific geographic coordinates and altitude not recorded; CAU.

\section{Description}

\section{Male}

Measurements. Body length $15.0 \mathrm{~mm}$, wing length $17.5 \mathrm{~mm}$, antenna length $5.0 \mathrm{~mm}(\mathrm{n}=1)$.

HEAD (Figs 66, 68). Mainly reddish yellow. Vertex with brownish black stripe. Rostrum and nasus dark yellow. Setae on head dark brown. Scape, pedicel and first flagellar segment yellow, other flagellar segments bicolor, yellowish with dark brown base. Proboscis brown; palpus yellowish brown.

Thorax (Figs 66, 68). Mainly reddish yellow with dark yellow pruinescence. Pronotum reddish yellow with yellow setae. Prescutum dark yellow with four reddish brown stripes, median stripes broadened apically and gradually narrowing to base, lateral stripes long-oval, dark reddish brown. Scutum almost entirely brown with four olive-gray pruinose spots. Scutellum and mediotergite dark yellow with dark gray mid-longitudinally. Thoracic pleuron reddish yellow. Anepisternum pale brown. Setae on thorax yellow. Legs with coxae and femora dark yellow, femora with dark brown apices and brown middle portion, tibiae and tarsi dark brown. Setae on legs dark brown. Wing variegated light brown; pterostigma brown; petiole of cell $\mathrm{m}_{1}$ shorter than discal cell (Fig. 67). Halter with stem yellow, knob pale yellow with dark brown lower margin.

Aвdomen (Figs 66, 68). Mainly yellow. Middle of abdominal tergites 1-2 with pale brown stripes, other tergites without spot. Abdominal segments 5-9 brown. Setae on abdomen yellow.

Hypopygium (Figs 69-73). Gonocoxite elongated, separated from sternite 9, gonocoxite ends with a sharp black upper spine, directed chiefly upward, bottom of gonocoxite also with a black upper spine (Figs 69, 73). Posterior margin of membranous suture between tergite 9 and gonocoxite with a spiny projection. Tergite 9 separated medially, with fleshy upper tergal lobes flattened, two widened sclerotized blades at a lower level, apex of blade black and serrulate. Sternite 9 with a median prominence; apex of appendages of sternite 9 slender, basally dilated. Outer gonostylus slender, strip-shaped; stem almost without setae (Fig. 71). Inner gonostylus with a subtriangular elevation, lower beak close to base of upper beak (Fig. 72).

\section{Female}

Unknown or unrecognized.

\section{Distribution}

China (Tibet). 

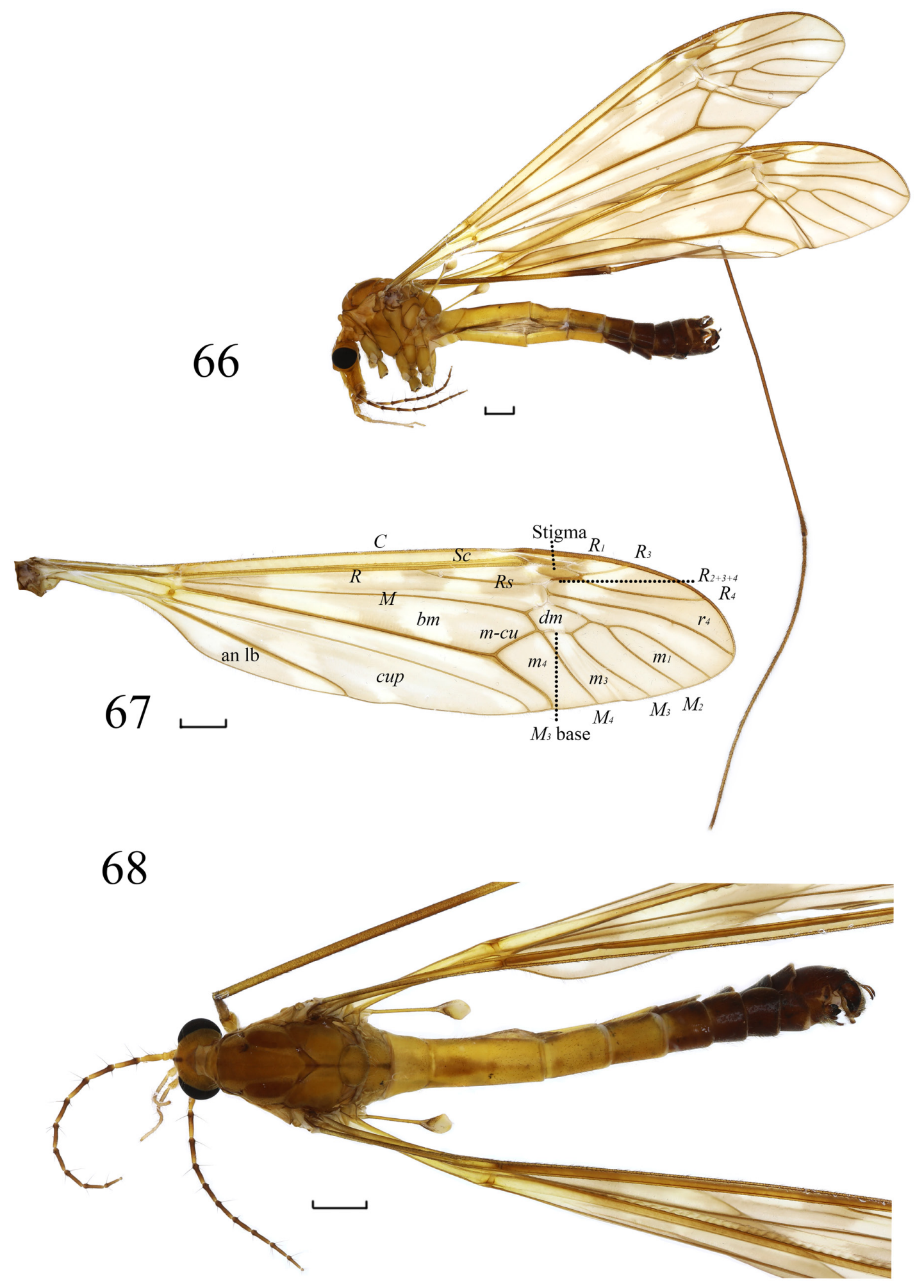

Figs 66-68. Tipula (Vestiplex) platyphylla sp. nov., holotype, đ (CAU). 66. Habitus, lateral view. 67. Wing. 68. Habitus, dorsal view. Abbreviations: see Material and methods. Scale bars $=1.0 \mathrm{~mm}$. 


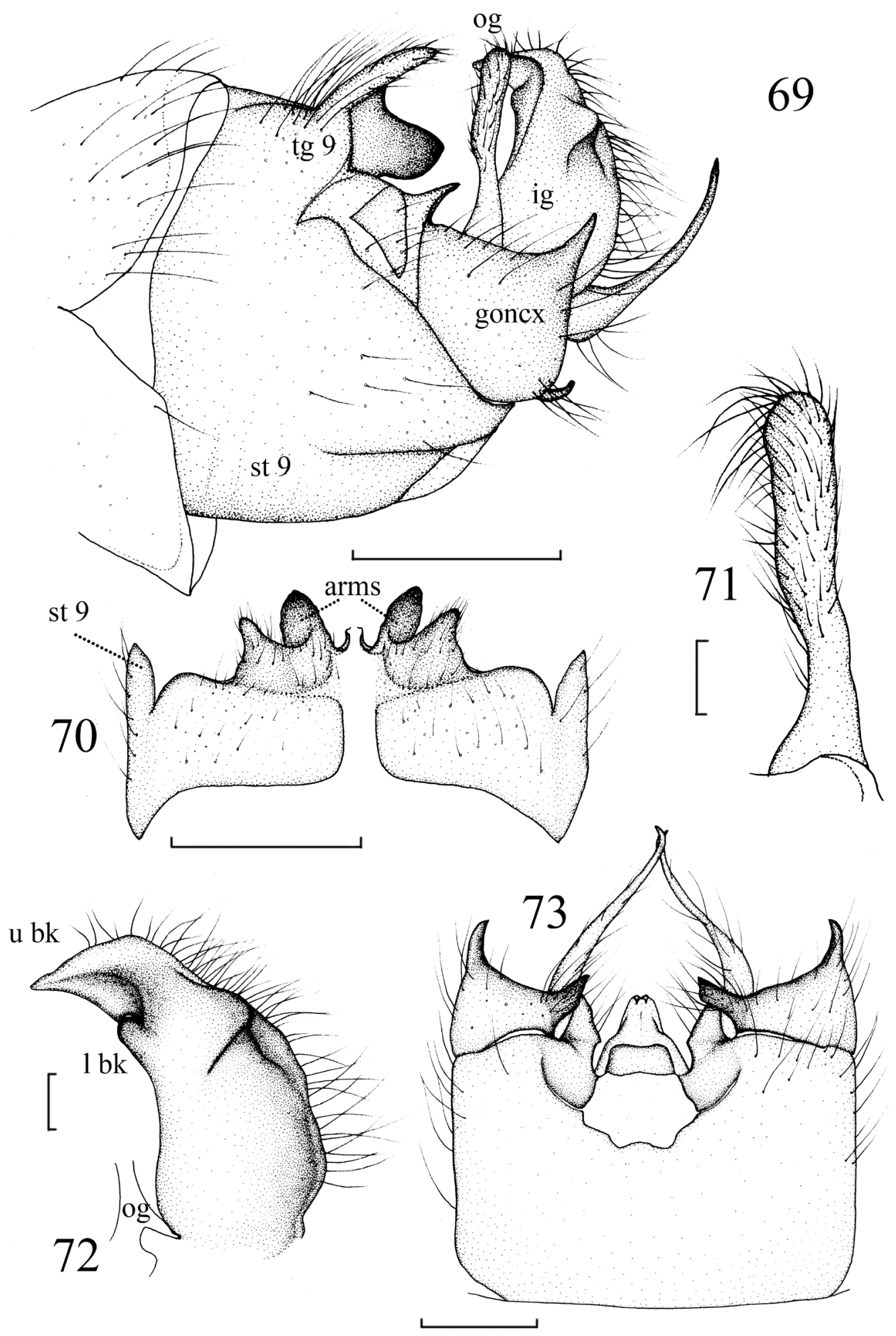

Figs 69-73. Tipula (Vestiplex) platyphylla sp. nov., holotype, $\partial \widehat{~(C A U) . ~ 69 . ~ H y p o p y g i u m, ~ l a t e r a l ~ v i e w . ~}$ 70. Tergite nine, dorsal view. 71. Outer gonostylus, lateral external view. 72. Inner gonostylus, lateral external view. 73. Hypopygium, ventral view. Abbreviations: see Material and methods. Scale bars: $69-70,73=0.5 \mathrm{~mm} ; 71-72=0.1 \mathrm{~mm}$. 


\section{Remarks}

The new species is similar to $T$. (V.) gandharva Alexander, 1951 from India (Assam) and Myanmar, but the latter differs in the following characters: dorsolateral extensions of tergite 9 long and slender, sclerotized ventral blades much less massive; the spine of gonocoxite is smaller than this new species.

\section{Other groups in Tibet}

\section{Tipula (Vestiplex) avicularia group}

Tipula (Vestiplex) avicularia Edwards, 1928

Tipula (Vestiplex) coquillettiana group

Tipula (Vestiplex) scandens Edwards, 1928

Tipula (Vestiplex) eurydice group

Tipula (Vestiplex) eurydice Alexander, 1961

Tipula (Vestiplex) scripta group

Tipula (Vestiplex) subscripta Edwards, 1928

Tipula (Vestiplex) virgatula group

Tipula (Vestiplex) opilionimorpha opilionimorpha Savchenko, 1955

\section{Group unknown}

Tipula (Vestiplex) motuoensis sp. nov.

Tipula (Vestiplex) motuoensis sp. nov. urn:1sid:zoobank.org:act:6536F0F9-0D40-490C-BEF5-06A3A1153033

Figs $75-83$

\section{Diagnosis}

Proboscis relatively short. Pronotum brownish yellow with dark yellow setae. Prescutum mainly reddish yellow with four olive-brown striped pruinescence, velvety, two middle stripes virtually fused. Gonocoxite ends hook-like, not separated from sternite 9; tergite 9 with two pairs of lobes, longitudinally divided into two parts, slightly connected, pair of emarginate arms arising from ventral surface of tergite 9. Inner gonostylus with posterior crest produced backward, base of inner gonostylus and outer basal lobe of inner gonostylus rolled inward, produced depression with row of short setulae.

\section{Etymology}

The species is named after the type locality Motuo.

\section{Material examined}

\section{Holotype}

CHINA • O'; Tibet, Motuo, 80K; 29³9'29" N, 95²9'24" E; 2020 m a.s.1.; 13 Jun. 2017; Qicheng Yang leg.; light trap; CAU.

\section{Allotype}

CHINA • $q$; same collection data as for holotype; CAU. 

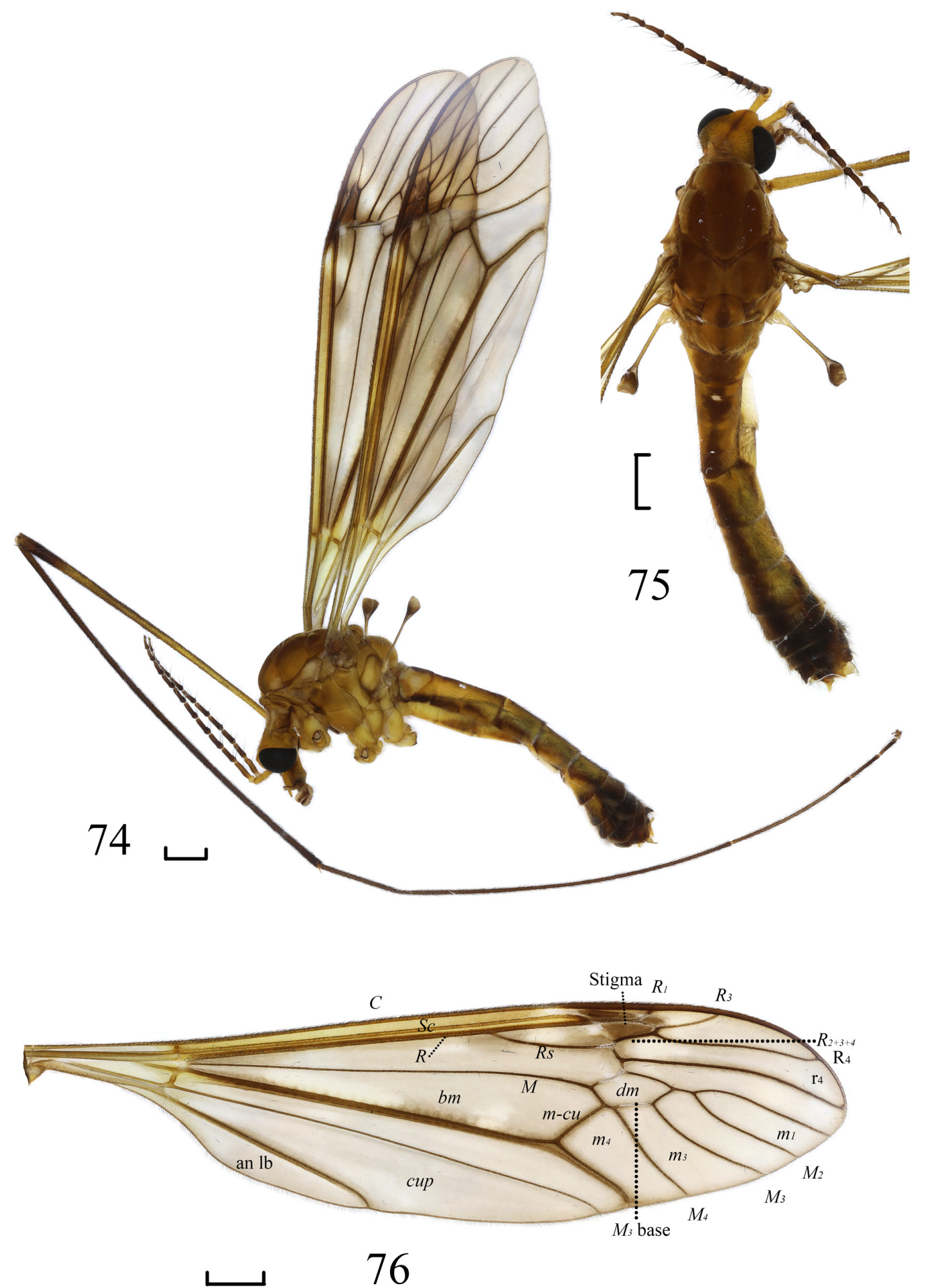

Figs 74-76. Tipula (Vestiplex) motuoensis sp. nov., holotype, $\widehat{\jmath}$ (CAU). 74. Habitus, lateral view. 75. Male habitus, dorsal view. 76. Wing. Abbreviations: see Material and methods. Scale bars $=1.0 \mathrm{~mm}$. 

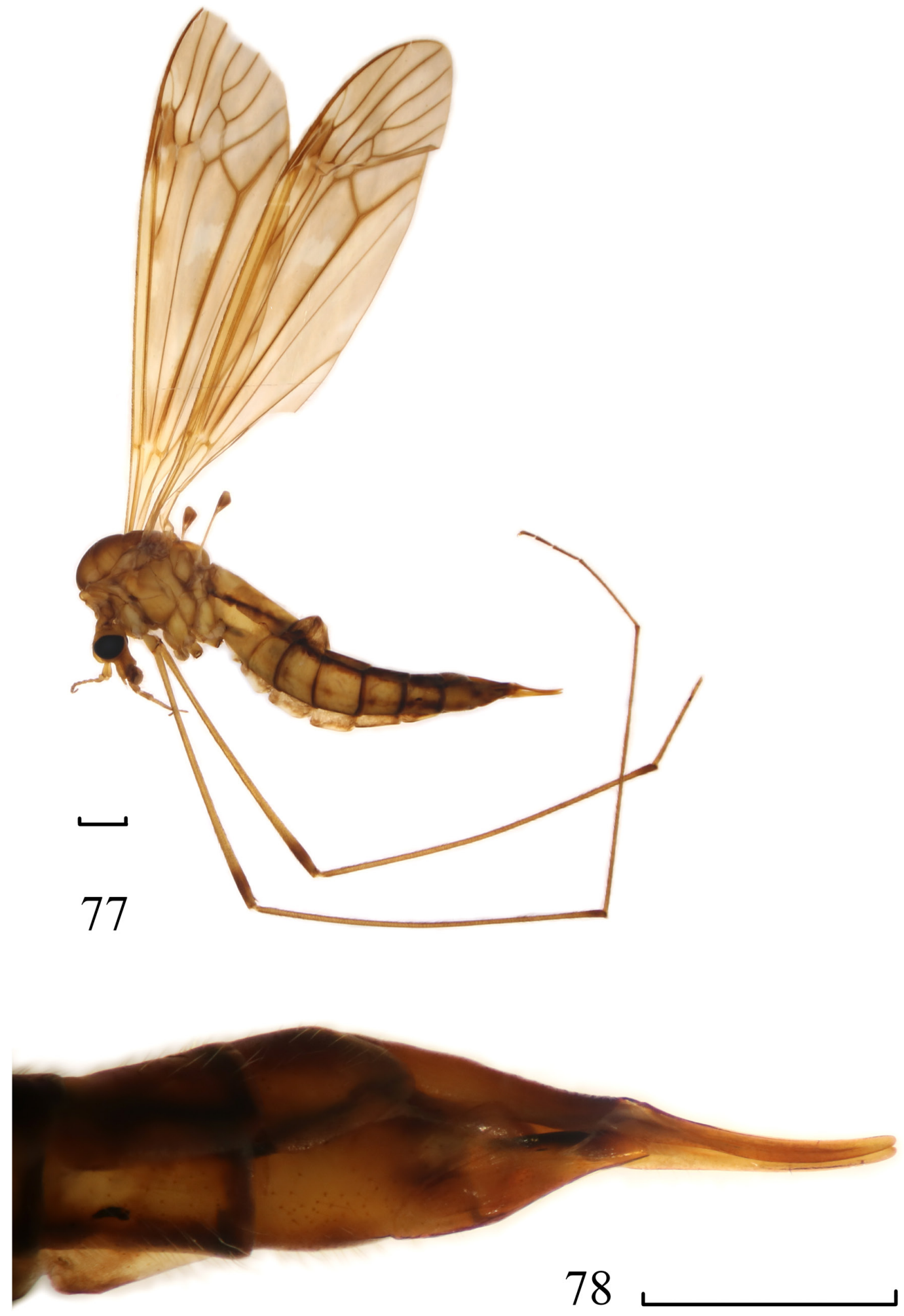

Figs 77-78. Tipula (Vestiplex) motuoensis sp. nov., allotype, $q$ (CAU). 77. Habitus, lateral view. 78. Ovipositor, lateral view. Scale bars $=1.0 \mathrm{~mm}$. 


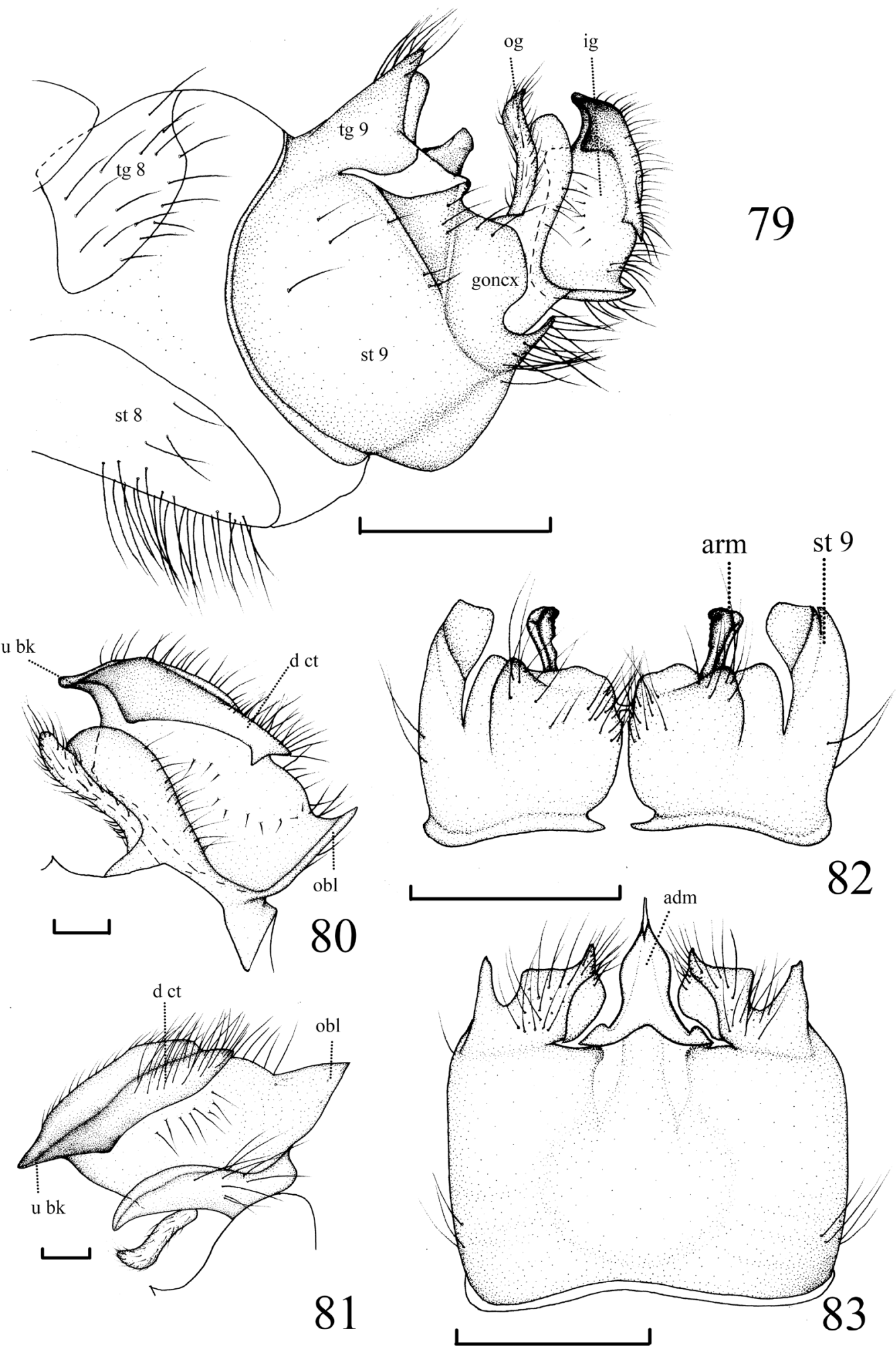

Figs 79-83. Tipula (Vestiplex) motuoensis sp. nov., holotype, ô (CAU). 79. Hypopygium, lateral view. 80-81. Outer and inner gonostylus, lateral external view and lateral dorsal view. 82. Tergite nine, dorsal view. 83. Hypopygium, ventral view. Abbreviations: see Material and methods. Scale bars: $79,82-83=$ $0.5 \mathrm{~mm} ; 80-81=0.1 \mathrm{~mm}$. 


\section{Paratype}

CHINA • 1 §̧; same collection data as for holotype; CAU.

\section{Description}

\section{Male}

Measurements. Body length $12.0 \mathrm{~mm}$, wing length $15.0 \mathrm{~mm}$, antenna length $4.0 \mathrm{~mm}(\mathrm{n}=2)$.

HEAD (Figs 74-75). Mainly dark yellow. Vertex with dark brown stripe. Frontal tubercle relatively high. Proboscis relatively short, rostrum and nasus dark yellow. Setae on head dark brown. Scape yellow, pedicel pale yellow, flagellum dark brown. Proboscis and palpus brownish yellow.

Thorax (Figs 74-75). Mainly dark yellow, heavily pruinescence. Pronotum brownish yellow with dark yellow setae. Prescutum mainly reddish yellow with four olive-brown striped pruinescence, velvety, two middle stripes virtually fused. Scutum with four reddish brown spots, with olive-brown striped pruinescence. Scutellum and mediotergite yellow with pale brown mid-longitudinal stripes. Thorax yellow in lateral view. Pleura below anterior thoracic spiracle to middle with an irregular brownish black spot; anepisternum and katepisternum pale brownish yellow. Setae on thorax yellow. Legs with coxae and bases of femora pale yellow, apices of femora brown; tibiae and tarsi dark brown. Setae on legs brownish black. Wing light brown; pterostigma brown; petiole of cell $\mathrm{m}_{1}$ shorter than discal cell (Fig. 76). Halter with stem dark yellow, knob brownish yellow.

Abdomen (Figs 74-75). Mainly yellow. Abdominal dorsum with three brown longitudinal stripes, abdominal segment 6 brownish yellow, segments 7-9 brown. Setae on abdomen dark brown and yellow.

Hypopygium (Figs 79-83). Gonocoxite ends hook-like, not separated from sternite 9, tergite 9 bearing two pairs of lobes, longitudinally divided into two parts, slightly connected, inner margin with dense setae; a pair of emarginate arms arising from ventral surface of tergite 9 , inner margin black, other areas yellow. Sternite 9 with a median prominence, middle of sternite 9 slightly raised. Sternite 8 with abundant setae. Outer gonostylus slender and small, apex curly (Figs 79-81). Inner gonostylus, dorsal crest produced into fishtail, base of inner gonostylus and outer basal lobe of inner gonostylus inward-rolled, produced depression with a row of short setulae, outer basal lobe of inner gonostylus large triangular (Figs 80-81).

\section{Female}

Measurements. Body length $13 \mathrm{~mm}$, wing length $15 \mathrm{~mm}$, antenna length $2.4 \mathrm{~mm}(\mathrm{n}=1)$.

Coloration. Body color slightly paler than male. Antenna shorter than male, dark yellow. Legs paler than male, tibiae and tarsi dark yellow. Abdominal tergites each with three stripes, middle stripe brown, lateral stripes brownish black, abdominal 7-8 segments yellowish brown, 8th segment dark brown. Junction of each 3-9 segments brownish black (Fig. 77).

OviPositor. Tergite 9 yellowish brown, tergite 10 yellow. Cercus dark yellow, slightly up-turned, outer margin without rough serration (Fig. 78).

\section{Distribution}

China (Tibet).

\section{Remarks}

The new species is similar to $T$. ( $V$.) theowaldana Alexander, 1964 from Assam, India, but the latter differs in the following characters: basal abdominal tergites yellow; gonocoxite ends sharp and not hooked; tergite 9 with a pair of larger and elongate lobes. The species may form a new species group, 

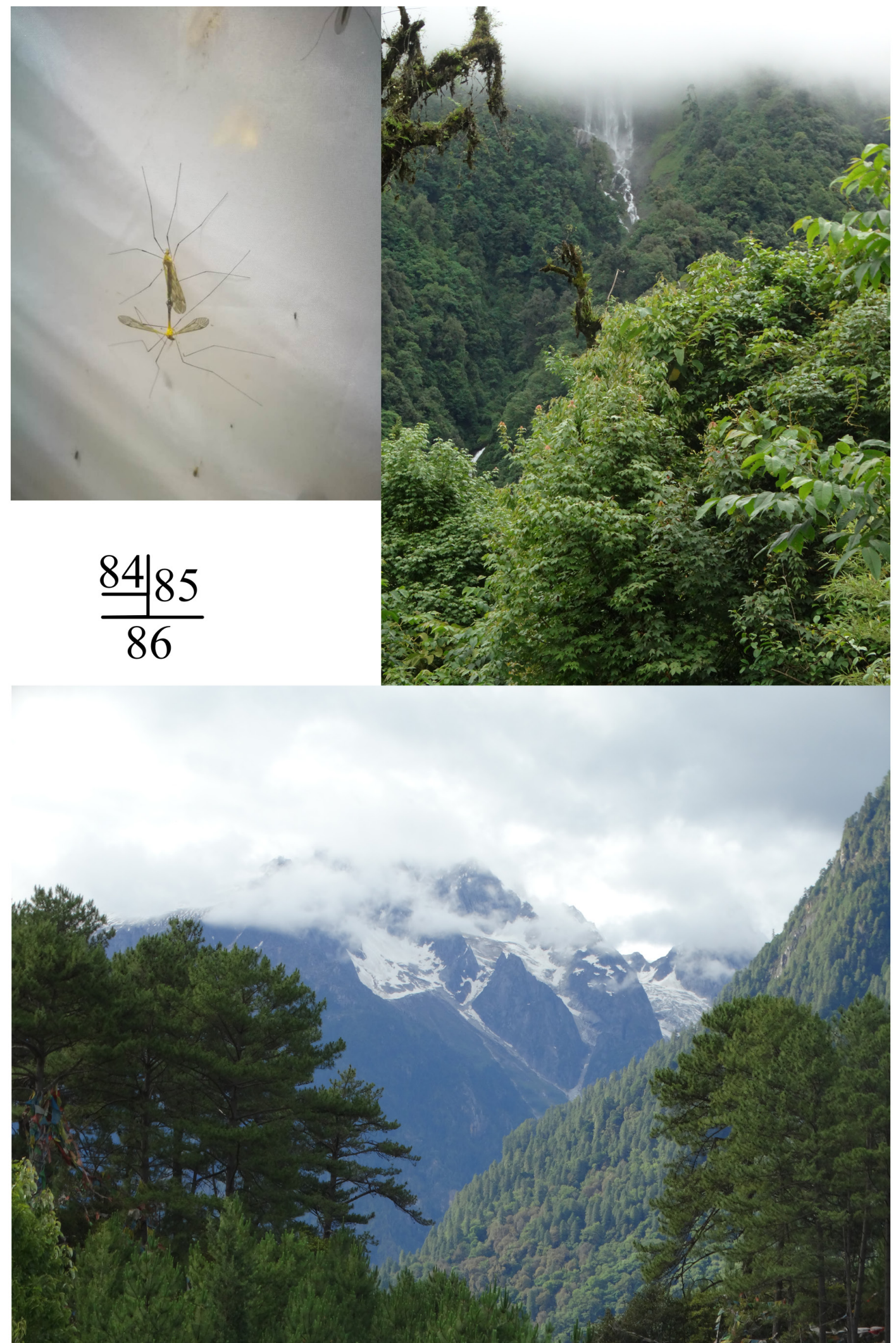

Figs 84-86. 84. Tipula (Vestiplex) bucera sp. nov., mating. 85. Habitat of $80 \mathrm{~K}$, Muotuo, Tibet, China. 86. Habitat of Yigong, Bomi, Tibet, China. 
perhaps together with $T$. $(V$.$) theowaldana. However, we have not examined the specimens of the latter$ species and can therefore not say with certainty if these two species share characteristics that would separate them from existing species groups.

\section{Discussion}

Starkevich (2012) divided the subgenus Vestiplex into 7 species groups in his revisionary study of the global fauna. The species diversity of Vestiplex is particularly high in northern India, the Tibetan Plateau and the Hengduan Mountains, with more than 90 species currently known (Oosterbroek 2021). We added six new species to the fauna of Tibet, and placed $T$. ( $V$.) magatama sp. nov. and $T$. (V.) uncinella sp. nov. into the $T$. ( $V$.) deserrata group; $T$. ( $V$.) nayogabuensis sp. nov. into the $T$. (V.) divisotergata group, $T$. (V.) bucera sp. nov. into the $T$. ( $V$.) himalayensis group; and placed $T$. (V.) platyphylla sp. nov. into the $T$. $(V$.) subtincta group. But we could not place $T$. $(V$.) motuoensis, which has an inner dististyle similar to that of $T$. (V.) theowaldana from India (Assam), in an existing species group. We hope to examine the specimens of $T$. ( $V$.) theowaldana in the future to determine whether $T$. ( $V$.) theowaldana and $T$. $(V$.) motuoensis can be placed in an existing species group.

\section{Acknowledgments}

Two anonymous reviewers are thanked for providing useful comments on an earlier draft of this paper. We are very grateful to Sigitas Podenas and Qifei Liu for their great help with the study of the specimens in USNM, and Jinlong Ren for their assistance in the study of the specimens in BMNH. The data in this research come from the Collaborative Innovation Center of Research and Development on Tibetan Characteristic Agricultural and Animal Husbandry Resources (the Plateau Ecology Research Platform). This work was supported by the Special Project Fund for the Development of Local Colleges and Universities supported by the Central Finance in 2016 (the Investigation of Insect Resources in Southeast Tibet). Our sincere thanks to South-East Tibetan plateau Station for integrated observation and research of alpine environment, Mr. Huiyi Ding (principal of Damu Township Primary School in Motuo County) for helping us in the collection, and Mr. Siyuan Xu for the identification of parasitic mites. We are also grateful to Mr Hui Wang (Bureau of Agriculture and Rural Affair of Chayu County) for providing us with specimens of $T$. $(V$. $)$ zayulensis, Mr Bing Zhang, Mr Liang Wang, and Ms Yue Liu for their assistance in examining specimens during the COVID-19 epidemic.

\section{References}

Alexander C.P. 1935. New or little-known Tipulidae from eastern Asia (Diptera). XXII. Philippine Journal of Science 55: 133-562.

Alexander C.P. 1942. The Oriental Tipulidae in the collection of the Indian museum. Part II. Records of the Indian Museum 44: 29-72.

Alexander C.P. 1953. The Oriental Tipulidae in the collection of the Indian museum. Part III. Records of the Indian Museum 50: 321-357.

Alexander C.P. 1958. Undescribed species of crane-flies from the Himalaya mountains (Tipulidae, Diptera). II. Journal of the New York Entomological Society 65: 147-157.

Alexander C.P. 1960. New or little-known Tipulidae from eastern Asia (Diptera). XLVI. Philippine Journal of Science 88: 137-184.

Alexander C.P. 1963. Some Tipulidae from Tibet and upper Burma in the British museum (natural history) (Diptera). Bulletin of the British Museum (Natural History), Entomology 14: 319-340.

https://doi.org/10.5962/bhl.part.8785 
Alexander C.P. 1965. New subgenera and species of crane-flies from California (Diptera: Tipulidae). Pacific Insects 7: 333-386. Available from http://hbs.bishopmuseum.org/pi/pi7-2.htm [accessed 9 Aug. 2021].

Alexander C.P. 1968. The crane flies (Trichoceridae and Tipulidae: Diptera). Khumbu Himal 3: 82-100.

Alexander C.P. \& Byers G.W. 1981. Tipulidae. In: McAlpine J.F., Peterson B.V., Shewell G.E., Teskey H.J., Vockeroth J.R. \& Wood D.M. (coords) Manual of Nearctic Diptera. Vol. 1: 153-190. Biosystematics Research Institute, Monograph 27, Ottawa, Ontario.

Bezzi M. 1924. Una nuova Tipula delle Alpi con ali ridotte anche nel maschio (Dipt.). Annali del Museo Civico di Storia Naturale di Genova 51: 228-233.

Brunetti E. 1911. Revision of the Oriental Tipulidae with descriptions of new species. Records of the Indian Museum 6: 231-314. https://doi.org/10.5962/bhl.part.21334

Cumming J.M \& Wood D.M. 2017. Adult morphology and terminology. In: Kirk-Spriggs A.H. \& Sinclair B.J. (eds) Manual of Afrotropical Diptera. Vol. 1. Introductory Chapters and Keys to Diptera Families: 107-151. Suricata 4, South African National Biodiversity Institute, Pretoria.

de Jong H. 2017. Limoniidae and Tipulidae (crane flies). In: Kirk-Spriggs A.H. \& Sinclair B.J. (eds) Manual of Afrotropical Diptera. Vol. 2. Nematocerous Diptera and Lower Brachycera: 427-477. Suricata 5, South African National Biodiversity Institute, Pretoria.

Edwards F.W. 1924. Notes on the types of Diptera Nematocera (Mycetophilidae and Tipulidae), described by Mr. E. Brunetti. Records of the Indian Museum 26: 291-307.

Edwards F.W. 1928. Some nematocerous Diptera from Yunnan and Tibet. Annals and Magazine of Natural History Series 10 1: 681-703. https://doi.org/10.1080/00222932808672840

Gelhaus J.K. 2005. Systematics and biogeography of the desert crane fly subgenus Tipula (Eremotipula) Alexander (Diptera: Tipulidae). Memoirs of the American Entomological Society 46: 1-235. Available from https://www.biodiversitylibrary.org/part/49845 [accessed 10 Aug. 2021].

Joseph A.N.T. 1974. The Brunetti types of Tipulidae (Diptera) in the collection of the Zoological Survey of India. Part III. Tipula Linnaeus. Oriental Insects 8: 241-280.

https://doi.org/10.1080/00305316.1974.10434860

Li J. \& Fang X. 1999. Uplift of the Tibetan Plateau and environmental changes. Chinese Science Bulletin 44 (23): 2117-2124. https://doi.org/10.1007/BF03182692

Li J., Liu H., Wu Y., Zeng L. \& Huang X. 2019. Spatial patterns and determinants of the diversity of hemipteran insects in the Qinghai-Tibetan Plateau. Frontiers in Ecology and Evolution 7: 165.

https://doi.org/10.3389/fevo.2019.00165

Men Q.L. 2015. Report on crane flies of the genus Tipula (Diptera: Tipulidae: Tipulinae) from Anhui Province, China. Acta Entomologica Musei Nationalis Pragae 55: 797-810.

Men Q.L., Young C.W., Starkevich P., Yu Y.F. \& Lei X.P. 2017. Two new species of Tipula (Vestiplex) from Southern China based on morphological and molecular data, with redescription of Tipula (Vestiplex) bicalcarata (Diptera, Tipulidae, Tipulinae). ZooKeys 658: 63-80.

https://doi.org/10.3897/zookeys.658.9738

Oosterbroek P. 2021. Catalogue of the Craneflies of the World (Diptera, Tipuloidea, Pediciidae, Limoniidae, Cylindrotomidae, Tipulidae). Available from https://ccw.naturalis.nl/ [accessed 11 Mar. 2021].

Pilipenko V.E., Starkevich P. \& Gavryushin D.I. 2019. A new Tipula (Vestiplex) Bezzi crane fly species (Diptera, Tipulidae) from Vietnam. Journal of the New York Entomologial Society 125: 10-15.

https://doi.org/10.1664/1947-5136-125.1.10 
Savchenko E.N. 1960. Scientific results of the Chinese-Soviet zoological-botanical expeditions of 19551957 to South-Western China. On the crane-flies (Diptera, Tipulidae) of SW China. Entomologicheskoe Obozrenie 39: 885-892.

Savchenko E.N. 1964. Crane-flies (Diptera, Tipulidae), Subfamily Tipulinae, Genus Tipula L., 2. Fauna USSR N.S. 89 Nasekomye Dvukrylye (Diptera) 2 (4): 1-503.

Starkevich P. 2012. Taxonomic and phylogentic review of the subgenus Tipula (Vestiplex) Bezzi, 1924 (Diptera, Tipulidae). Summary of PhD Thesis, Vilnius University, Biomedical Sciences, Zoology: 1-33.

Starkevich P. \& Podenas S. 2011. New faunistic records of Tipula (Vestiplex) crane flies (Diptera: Tipulidae) for China and Myanmar. Acta Zoologica Lituanica 21: 273-278.

https://doi.org/10.2478/v10043-011-0030-2

Starkevich P., Podenas S. \& Gelhaus J.K. 2020. Taxonomic review of Tipula (Vestiplex Bezzi) crane flies (Diptera: Tipulidae) in Mongolia. Zootaxa 4837: 1-88. https://doi.org/10.11646/zootaxa.4837.1.1

Su T., Spicer R.A., Li S.H., Xu H., Huang J., Sherlock S., Huang Y.J., Li S.F., Wang L., Jia L.B., Deng W.Y.D., Liu J., Deng C.L., Zhang S.T., Valdes P.J. \& Zhou Z.K. 2019. Uplift, climate and biotic changes at the Eocene-Oligocene transition in south-eastern Tibet. National Science Review 6 (3): 495504. https://doi.org/10.1093/nsr/nwy062

Manuscript received: 6 October 2019

Manuscript accepted: 30 June 2021

Published on: 27 August 2021

Topic editor: Nesrine Akkari

Section editor: Torbjørn Ekrem

Desk editor: Pepe Fernández

Printed versions of all papers are also deposited in the libraries of the institutes that are members of the EJT consortium: Muséum national d'histoire naturelle, Paris, France; Meise Botanic Garden, Belgium; Royal Museum for Central Africa, Tervuren, Belgium; Royal Belgian Institute of Natural Sciences, Brussels, Belgium; Natural History Museum of Denmark, Copenhagen, Denmark; Naturalis Biodiversity Center, Leiden, the Netherlands; Museo Nacional de Ciencias Naturales-CSIC, Madrid, Spain; Real Jardín Botánico de Madrid CSIC, Spain; Zoological Research Museum Alexander Koenig, Bonn, Germany; National Museum, Prague, Czech Republic. 